\title{
Potassium Capture by Kaolin, Part 1: KOH
}

Wang, Guoliang; Jensen, Peter Arendt; Wu, Hao; Jappe Frandsen, Flemming; Sander, Bo; Glarborg, Peter

Published in:

Energy and Fuels

Link to article, DOI:

10.1021/acs.energyfuels.7b03645

Publication date:

2018

Document Version

Peer reviewed version

Link back to DTU Orbit

Citation (APA):

Wang, G., Jensen, P. A., Wu, H., Jappe Frandsen, F., Sander, B., \& Glarborg, P. (2018). Potassium Capture by Kaolin, Part 1: KOH. Energy and Fuels, 32(2), 1851-1862. https://doi.org/10.1021/acs.energyfuels.7b03645

\section{General rights}

Copyright and moral rights for the publications made accessible in the public portal are retained by the authors and/or other copyright owners and it is a condition of accessing publications that users recognise and abide by the legal requirements associated with these rights.

- Users may download and print one copy of any publication from the public portal for the purpose of private study or research.

- You may not further distribute the material or use it for any profit-making activity or commercial gain

- You may freely distribute the URL identifying the publication in the public portal

If you believe that this document breaches copyright please contact us providing details, and we will remove access to the work immediately and investigate your claim. 


\title{
Potassium-capture by Kaolin. Part 1: KOH
}

\author{
Guoliang Wang ${ }^{\gamma^{*}}$, Peter Arendt Jensen ${ }^{\dagger}$, Hao Wu ${ }^{\dagger}$, Flemming Jappe Frandsen ${ }^{\dagger}$, Bo Sander ${ }^{\dagger \dagger}$, Peter \\ Glarborg $^{+}$
}

\author{
†Department of Chemical and Biochemical Engineering, Technical University of Denmark, Søltofts \\ Plads, Building 229, DK-2800 Kgs. Lyngby, Denmark \\ ${ }^{\dagger}$ Ørsted Bioenergy \& Thermal Power A/S, Kraftvæksvej 53, 7000 Fredericia, Denmark
}

Keywords: kaolin, potassium-capture, biomass combustion, additive, $\mathrm{KOH}$

*Corresponding author email-id: guow@kt.dtu.dk

\begin{abstract}
The reaction of gaseous $\mathrm{KOH}$ with kaolin and mullite powder at suspension-fired conditions was studied by entrained flow reactor (EFR) experiments. A water based slurry containing kaolin/mullite and $\mathrm{KOH}$ was fed into the reactor and the reacted solid samples were analyzed to quantify the K-capture level. The effect of reaction temperature, K-concentration in the flue gas and thereby molar ratio of $\mathrm{K} /(\mathrm{Al}+\mathrm{Si})$ in reactants, gas residence time, and solid particle size on $\mathrm{K}$-capture reaction was systematically investigated. Corresponding equilibrium calculations were conducted with FactSage 7.0. The experimental results showed that kaolin reached almost full conversion to Kaluminosilicates at suspension-fired conditions at $1100-1450{ }^{\circ} \mathrm{C}$ for a residence time of $1.2 \mathrm{~s}$ and a particle size of $\mathrm{D}_{50}=5.47 \mu \mathrm{m}$. The amount of potassium captured by kaolin generally followed the equilibrium at temperatures above $1100{ }^{\circ} \mathrm{C}$, but lower conversion was observed at $800{ }^{\circ} \mathrm{C}$ and $900{ }^{\circ} \mathrm{C}$.
\end{abstract}


Crystalline kaliophilite $\left(\mathrm{KAlSiO}_{4}\right)$ was formed at higher temperatures $\left(1300{ }^{\circ} \mathrm{C}\right.$ and $\left.1450{ }^{\circ} \mathrm{C}\right)$, whereas, amorphous K-aluminosilicate was formed at lower temperatures. Coarse kaolin $\left(\mathrm{D}_{50}=13.48 \mu \mathrm{m}\right)$ captured KOH less effectively than normal $\left(\mathrm{D}_{50}=5.47 \mu \mathrm{m}\right)$ and fine $\left(\mathrm{D}_{50}=3.51 \mu \mathrm{m}\right)$ kaolin powder at $1100{ }^{\circ} \mathrm{C}$ and $1300{ }^{\circ} \mathrm{C}$. The difference was less significant at $900{ }^{\circ} \mathrm{C}$. Mullite generated from kaolin captured $\mathrm{KOH}$ less effectively than kaolin at temperatures below $1100{ }^{\circ} \mathrm{C}$. However, at $1300{ }^{\circ} \mathrm{C}$ and $1450^{\circ} \mathrm{C}$, the amount of potassium captured by mullite became comparatively to that of kaolin.

\section{Introduction}

Suspension-combustion boilers (also called pulverized fuel combustion boilers) are increasingly used for production of power and heat from biomass. ${ }^{1,2}$ Combustion of biomass in suspension-fired boilers can produce renewable, $\mathrm{CO}_{2}$-neutral electricity with a higher electrical efficiency compared with that of grate-fired boilers. ${ }^{3}$ However, during the combustion process of biomass, significant amounts of Kspecies, such as $\mathrm{KOH}, \mathrm{KCl}$ and $\mathrm{K}_{2} \mathrm{SO}_{4}$, are released to gas phase in the boiler chamber, and this leads to deposit formation, corrosion ${ }^{4-12}$ as well as de-activation of SCR (Selective Catalytic Reduction) catalysts. ${ }^{13-18}$ Ash deposition and corrosion problems may be mitigated by reducing the super heater temperature. However, this will cause a reduced electrical efficiency of power plants. ${ }^{3,19-22}$

To minimize the ash related problems in biomass combustion, different treatments and processing technologies have been developed, including use of alkali scavenging additives, ${ }^{23-30}$ co-combustion with other biofuels or fossil fuels that are rich in $\mathrm{Si}$ or $\mathrm{Al},{ }^{31-35}$ utilizing effective deposit removal techniques, ${ }^{36}$ and a combination of different thermo-chemical processes. ${ }^{37,}{ }^{38}$ Among these, using additives is a promising option, primarily due to its high effectiveness and low requirements for boiler. 
The basic principle of additive use is that the additives are injected to boilers to react with the problematic gaseous $\mathrm{K}$-salts (such as $\mathrm{KOH}$ and $\mathrm{KCl}$ ), forming $\mathrm{K}$-species (such as $\mathrm{K}$-aluminosilicates) with low corrosivity and high melting temperatures. 2, 23, 26, 27, 29, 39-46 Biomass firing additives can generally be categorized into Al-Si based, S-based, P-based and Ca-based, according to the major elements present in the additives. ${ }^{2,42,47-50}$

Kaolin ${ }^{51-55}$ and coal fly ash $^{52}$ are typical Al-Si based additives for biomass combustion and have been studied in laboratory-scale experiments. In addition, coal fly ash has been utilized in full-scale biomass suspension-firing boilers in Denmark, and has been shown to have the capacity to significantly remedy deposition and corrosion problems. ${ }^{29,40}$ The mineralogical composition of coal fly ash is complex; including mainly mineral phases such as quartz, mullite, kaolinite, illite, siderite, etc. ${ }^{56,57}$ Among these mineral phases, kaolinite has been shown to be one of the most effective one for K-capture. ${ }^{58}$ Kaolinite is a layered aluminosilicate mineral with chemical formula of $\mathrm{Al}_{2} \mathrm{Si}_{2} \mathrm{O}_{5}(\mathrm{OH})_{4}$. Kaolin is a kind of clay that is rich in kaolinite. Investigating the K-capture reaction by kaolin is important for obtaining an improved understanding of K-capture by coal fly ash.

Kaolin undergoes complex transformation when being heated up. Above $450{ }^{\circ} \mathrm{C}$, kaolin transfers into metakaolin via a dehydroxylation reaction as shown in reaction $\mathrm{R} 1 .^{51}$ Metakaolin is a type of amorphous aluminosilicate that reacts effectively with gaseous K-salts. ${ }^{51}$ Metakaolin further transforms into spinel structure and amorphous $\mathrm{SiO}_{2}$ when it is heated to above $980{ }^{\circ} \mathrm{C}$, see reaction R2. Mullite starts to form at around $1100{ }^{\circ} \mathrm{C}$, and its amount increases with temperature and time, according to reaction $\mathrm{R} 3{ }^{59}$ At temperatures above $1400{ }^{\circ} \mathrm{C}$, needle shaped mullite grains are formed, and the size and the aspect ratio of the mullite grains increase with increasing calcination temperature. ${ }^{59}$ Generally, compared to metakaolin, mullite is believed to be less reactive for alkali capture. ${ }^{52}$ Thus the 
transformation of kaolin at high temperatures may influence the K-capture reaction. To achieve the best K-capture results, kaolin should be injected into boilers at an optimal temperature window.

$$
\begin{gathered}
\mathrm{Al}_{2} \mathrm{Si}_{2} \mathrm{O}_{5}(\mathrm{OH})_{4}(\text { kaolin }) \rightarrow \mathrm{Al}_{2} \mathrm{O}_{3} \cdot 2 \mathrm{SiO}_{2}(\text { metakaolin })+2 \mathrm{H}_{2} \mathrm{O}(\mathrm{g}) \\
\mathrm{Al}_{2} \mathrm{O}_{3} \cdot 2 \mathrm{SiO}_{2}(\text { metakaolin }) \rightarrow \mathrm{Al}_{2} \mathrm{O}_{3} \cdot \mathrm{SiO}_{2}(\text { spinel })+\mathrm{SiO}_{2}(\text { amorphous }) \\
\left.3\left(\mathrm{Al}_{2} \mathrm{O}_{3} \cdot \mathrm{SiO}_{2}\right)(\text { spinel })+3 \mathrm{SiO}_{2}(\text { amorphous }) \rightarrow 3 \mathrm{Al}_{2} \mathrm{O}_{3} \cdot 2 \mathrm{SiO}_{2} \text { (mullite }\right) \\
+4 \mathrm{SiO}_{2} \text { (amorphous) }
\end{gathered}
$$

Alkali-capture, especially the Na-capture reaction by kaolin has been widely studied primarily due to its application for cleaning Na-species from hot flue gases in Combined Cycle Gas Turbine (CCGT) power plants $^{60-62}$ and for dealing with ash-related problems in combustion of Na-rich low rank coals in power plant boilers. ${ }^{28,63-66}$ However, when it comes to biomass combustion, K-capture reaction is of greater concern, but it has been studied to a less extent. ${ }^{51}$

Gas phase release and speciation of potassium depends on many factors including combustion conditions, fuel ash transformation chemistry, etc. In the combustion of biomass with high K but low $\mathrm{Cl}$ and $\mathrm{S}$ contents, $\mathrm{KOH}(\mathrm{g})$ is the dominant $\mathrm{K}$-species in the high temperature flue gas. ${ }^{67,68}$ When $\mathrm{S}$ and $\mathrm{Cl}$ are available, $\mathrm{KCl}$ and $\mathrm{K}_{2} \mathrm{SO}_{4}$ would be formed during the combustion process, but at high temperature $\mathrm{KCl}$ and $\mathrm{K}_{2} \mathrm{SO}_{4}$ can also transfer into $\mathrm{KOH}$ in the presence of water. ${ }^{51}$

$\mathrm{KOH}$ is a troublesome K-species and the main reactions involved for kaolin/metakaolin to capture $\mathrm{KOH}$ are shown in reaction $\mathrm{R} 4$ and $\mathrm{R} 5{ }^{67}$ The two main products are kalsilite $\left(\mathrm{KAlSiO}_{4}\right)$ and leucite $\left(\mathrm{KAlSi}_{2} \mathrm{O}_{6}\right)$ with melting temperatures above $1600{ }^{\circ} \mathrm{C}$ and $1500{ }^{\circ} \mathrm{C}$, respectively. Therefore, the meltinduced slagging and corrosion in biomass-fired boilers could be significantly mitigated by the use of kaolin. ${ }^{3,22,69}$ However, the kinetics and detailed knowledge on the $\mathrm{KOH}$-capture reaction by kaolin is still limited, especially, for suspension combustion. 


$$
\begin{gathered}
\mathrm{Al}_{2} \mathrm{O}_{3} \cdot 2 \mathrm{SiO}_{2}(\text { metakaolin })+2 \mathrm{KOH} \rightarrow 2 \mathrm{KAlSiO}_{4}(\text { kalsilite })+\mathrm{H}_{2} \mathrm{O} \\
\left.\mathrm{Al}_{2} \mathrm{O}_{3} \cdot 2 \mathrm{SiO}_{2} \text { (metakaolin }\right)+2 \mathrm{KOH}+2 \mathrm{SiO}_{2} \rightarrow 2 \mathrm{KAlSi}_{2} \mathrm{O}_{6}(\text { leucite })+\mathrm{H}_{2} \mathrm{O}
\end{gathered}
$$

To the author's knowledge, the only literature available on alkali-capture by dispersed kaolin particles at suspension-fired conditions is the experimental study by Wendt and co-authors ${ }^{63,70,71}$ done in a $17-\mathrm{kW}$ down-flow combustor which simulated the conditions in suspension-fired boilers. A sodium acetate solution was injected in the reactor to produce a Na vapor. The effect of temperature, residence time as well as the presence of sulfur and chlorine on the Na-capture reaction was studied. Results showed that the rate of $\mathrm{NaOH}$ adsorption was higher than that of $\mathrm{NaCl}$, and they proposed that $\mathrm{NaOH}$ is the only reacting species in both cases. However, whether the kinetics of $\mathrm{Na}$ and $\mathrm{K}$ capture by kaolin are the same has not been established. ${ }^{52}$

Gaseous $\mathrm{KOH}$ capture by kaolin pellets (around $1 \mathrm{~mm}$ ) in a fixed bed was studied by Steenari and co-workers. ${ }^{51,72,73}$ They found that kaolin captured $\mathrm{KCl}$ more effectively than $\mathrm{KOH}$, indicating that $\mathrm{KCl}$ and $\mathrm{KOH}$ can both react directly with kaolin. The $\mathrm{KOH}$ concentration was very low in these studies, with a typical $\mathrm{KOH}$-concentration of $1.1 \mathrm{ppm}$, which is far below the $\mathrm{K}$-concentration in biomass suspension-fired boilers. ${ }^{5}$

The degree of conversion of kaolin to K-aluminosilicates may be limited by equilibrium constrains. In addition, the rate of reaction may be limited by the external and internal diffusion of the gaseous potassium species, and by the reaction kinetics. Typically, a decreased kaolin particle size and/or an increased residence time lead to an increased conversion to the products.

At suspension-fired conditions, the reaction between gaseous $\mathrm{KOH}$ and dispersed kaolin particles may be affected by the local temperature, the additive particle size and composition, and the reaction time. Understanding the influence of different parameters on the K-capture reaction is crucial and 
helpful for providing recommendation for optimal utilization of kaolin and coal fly ash in full-scale boilers.

The objective of this work is to develop a method to study the K-capture reactions by solid additives at well-controlled suspension-fired conditions, and to systematically investigate the impact of different parameters on the K-capture reaction by solid additives, such as reaction temperature, Kconcentration/molar ratio of $\mathrm{K} /(\mathrm{Al}+\mathrm{Si})$ in the reactant, kaolin particle size, gas residence time and the high temperature transformation of kaolin. This paper is Part 1 of a series of two papers studying the potassium capture by kaolin. This paper focuses on the $\mathrm{KOH}$ capture by kaolin, and the second one focuses on the $\mathrm{K}$-capture reaction by kaolin using $\mathrm{KCl}, \mathrm{K}_{2} \mathrm{CO}_{3}$ and $\mathrm{K}_{2} \mathrm{SO}_{4}$.

\section{Experimental section}

\subsection{Materials}

Kaolin powders of three different particle sizes and a mullite powder were utilized in this study. The particle size distribution (PSD) of the materials was analyzed with a Malvern 3000 particle size distribution analyzer. Based on the PSD, the three kaolin powders are named as normal kaolin powder $\left(\mathrm{D}_{50}=5.47 \mu \mathrm{m}\right)$, fine kaolin powder $\left(\mathrm{D}_{50}=3.51 \mu \mathrm{m}\right)$, and coarse kaolin powder $\left(\mathrm{D}_{50}=13.48 \mu \mathrm{m}\right)$. The normal kaolin powder was purchased from VWR Chemicals, and the fine kaolin powder was generated by grinding the normal kaolin powder in a ball mill. The coarse kaolin powder was obtained by grinding kaolin stones purchased from Ward's Science. Mullite powder was generated by heat

treatment of the normal kaolin powder $\left(\mathrm{D}_{50}=5.47 \mu \mathrm{m}\right)$ at $1100{ }^{\circ} \mathrm{C}$ for 24 hours. ${ }^{59}$ The calcinated mullite sample was re-grinded, to break the agglomerated blocks, and to get a $\mathrm{D}_{50}$ of $5.90 \mu \mathrm{m}$, which is similar to that of the normal kaolin powder $\left(\mathrm{D}_{50}=5.47 \mu \mathrm{m}\right)$. 
The materials were analyzed by ICP-OES (Inductively Coupled Plasma Atomic Emission Spectroscopy) and XRD (X-ray Diffraction), for elemental composition and mineralogical composition. The elemental composition of the three kaolin samples was similar, as shown in Table 1. The molar $(\mathrm{Na}+\mathrm{K}) /(\mathrm{Si}+\mathrm{Al})$ ratio of the three kaolin samples is around 0.02 , indicating that a large fraction of $\mathrm{Al}$ and $\mathrm{Si}$ are available for $\mathrm{K}$-capture through reaction $\mathrm{R} 4$ and $\mathrm{R} 5$. The molar $\mathrm{Si} / \mathrm{Al}$ ratio of the normal and the coarse kaolin powder is 1.12 and 1.17, respectively, which is higher than the theoretical molar Si/Al ratio of kaolinite $\left(\mathrm{Al}_{2} \mathrm{Si}_{2} \mathrm{O}_{5}(\mathrm{OH})_{4}\right)$. This is due to the presence of quartz $\left(\mathrm{SiO}_{2}\right)$, confirmed by the XRD spectrum of the kaolin powder shown in Figure 1.

As shown in Table 1, the BET surface area of the normal kaolin is $12.70 \mathrm{~m}^{2} / \mathrm{g}$. The BET surface area of the fine and coarse kaolin is similar to that of normal kaolin. However, the BET surface area of mullite is much smaller than that of the parental kaolin, implying a significant sintering process during the mullite preparation process.

The XRD spectra of the normal kaolin, coarse kaolin and the mullite are shown in Figure 1. The XRD spectrum of the fine kaolin is the same as that of the normal kaolin, and thus is not included. The spectra show that kaolinite $\left(\mathrm{Al}_{2} \mathrm{Si}_{2} \mathrm{O}_{5}(\mathrm{OH})_{4}\right)$ and quartz $\left(\mathrm{SiO}_{2}\right)$ are the main mineral phases in the three kaolin samples. In the mullite sample, mullite $\left(3 \mathrm{Al}_{2} \mathrm{O}_{3} \cdot 2 \mathrm{SiO}_{2}\right)$ and quartz $\left(\mathrm{SiO}_{2}\right)$ are detected as the main mineral phases. No kaolinite was detected in the mullite sample, indicating a complete transformation from kaolinite to mullite during heat treatment.

\subsection{Setup}

Experiments were conducted in the DTU Entrained Flow Reactor (EFR), as shown in Figure 2, which can simulate the conditions in suspension-fired boilers. The EFR consists of a gas supply system, a liquid/slurry sample feeding system, a gas preheater, a vertical reactor which is electrically 
heated by 7 heating elements, a bottom chamber and a particle and a flue gas extraction system. The vertical reactor tube is 2-meter long, and the inner diameter is $79 \mathrm{~mm}$. The reactor can be heated up to $1450{ }^{\circ} \mathrm{C}$. A $0.8 \mathrm{~m}$ long preheater is placed above the reactor tube for preheating the secondary gas.

To obtain a high $\mathrm{KOH}$ vaporization degree and a good contact of salt vapor to additives, a slurry containing $\mathrm{KOH}$ and kaolin was fed into the EFR, instead of feeding solid $\mathrm{KOH}$ and kaolin powder into the reactor directly. ${ }^{74,75}$ The slurry was subsequently fed into the reactor, using a peristaltic pump through a water-cooled feeding probe, as shown in Figure 3. During each experiment, the slurry was stirred with a magnetic stirrer to keep it homogeneous.

The slurry also contained ethanol, which combusted in the reactor producing $\mathrm{CO}_{2}$. Therefore, the feeding rate stability can be indirectly monitored by measuring the $\mathrm{CO}_{2}$ concentration in the flue gas. Slurry fed into the reactor was atomized, at the outlet of the water-cooled feeding probe by a $30 \mathrm{Nl} / \mathrm{min}$ primary air flow, as shown in Figure 3. The atomized slurry droplets were mixed with the preheated secondary air and subsequently evaporated. $\mathrm{KOH}$ transferred into gas phase and reacted with solid additives (kaolin or mullite) in the reactor tube. At the outlet of the reactor, the flue gas and the entrained solid samples entered into a water-cooled bottom chamber, where the flue gas was divided into two fractions, with around $50 \%$ going to the sampling probe and subsequently to the solid sampling line, while the remaining $50 \%$ vent to the ventilation, directly. The sampling probe is about 1.5 meters long and is air-cooled, keeping the flue gas temperature at around $300{ }^{\circ} \mathrm{C}$. A $10 \mathrm{Nl} / \mathrm{min}$ quench gas was introduced at the inlet of the sampling probe, for quenching the flue gas and the reaction. The quenching gas also helped to prevent the deposition of solid samples on the inner wall of the sampling tube. The entrained large solid particles and aerosols were captured, respectively, by a cyclone (with a cut-off diameter of $2.3 \mu \mathrm{m}$ ) and a metal filter (with a pore size of $0.8 \mu \mathrm{m}$ ) in the 
sampling line. The cyclone and filter were both heated to $200{ }^{\circ} \mathrm{C}$, to avoid condensation of water vapor. Each experiment lasted about $60 \mathrm{~min}$, and the solid samples were collected for further analysis.

In order to avoid unexpected air leakage into the EFR, the reactor was operated at a pressure slightly higher (approximately 1.0-3.0 mbar) than the atmospheric pressure, and the possible gas escaping from the reactor was captured by a shell around the reactor and pumped to ventilation.

\subsection{Experimental matrix}

Two sets of experiments were conducted in the EFR: $\mathrm{KOH}$ evaporation experiments and $\mathrm{KOH}-$ capture experiments using kaolin of three different particle sizes, and mullite. The experimental conditions are summarized in Table 2, and more detailed information is available in Appendix I of the supplementary material. In the $\mathrm{KOH}$ evaporation experiments (experiment series (A) in Table 2), $\mathrm{KOH}$ solution was injected into the EFR without solid additives, to study the evaporation and transformation behavior of $\mathrm{KOH}$ at high temperature. The concentration of $\mathrm{KOH}$ in the flue gas was kept at $500 \mathrm{ppmv}$. The mass of solid samples collected in the cyclone and filter were weighted to study the vaporization of KOH. Additionally, the collected solid samples were analyzed with XRD to determine the transformation of $\mathrm{KOH}$ at high temperatures.

In the KOH-capture experiments (experiment series ( $\mathrm{B}$ to $\mathrm{F}$ ) in Table 2), a slurry containing both $\mathrm{KOH}$ and kaolin/mullite was injected into the EFR. In all the $\mathrm{KOH}$-capture experiments, the concentration of kaolin in the flue gas was kept constant, while the amount of $\mathrm{KOH}$ in the feeding slurry was adjusted. Thereby, the concentration of $\mathrm{KOH}$ in the flue gas was changed consequently. The $\mathrm{KOH}$-concentration (K-concentration in Table 2) in the flue gas was changed from 50 ppmv to 1000 ppmv, and the molar ratio of $\mathrm{K} /(\mathrm{Al}+\mathrm{Si})$ in reactants was changed from 0.048 to 0.961 correspondingly. 


\subsection{Analytical methods}

To quantify the amount of potassium captured by kaolin, the reacted solid samples were analyzed with ICP-OES (Inductively Coupled Plasma Atomic Emission Spectroscopy). The concentration of major elements ( $\mathrm{Al}, \mathrm{Ca}, \mathrm{Fe}, \mathrm{Mg}, \mathrm{P}, \mathrm{S}, \mathrm{K}, \mathrm{Si}, \mathrm{Na}$ and $\mathrm{Ti}$ ) was determined according to the Danish Standard of DS/EN 15290 (Solid Biofuels- Determination of Major Elements). The standard DS/EN ISO 16995 (Solid Biofuels- Determination of water soluble Chloride, Sodium and Potassium) was used to determine the concentration of water-soluble $\mathrm{K}$ and $\mathrm{Cl}$. The concentration of total potassium and water-soluble potassium of product samples were both analyzed.

Two parameters were defined for quantifying the amount of potassium captured by kaolin: the Kconversion $\left(\mathrm{X}_{\mathrm{K}}\right)$, and the $\mathrm{K}$-capture level $\left(\mathrm{C}_{\mathrm{K}}\right) . \mathrm{X}_{\mathrm{K}}$ is defined as the percentage (\%) of input $\mathrm{KOH}$ chemically captured by solid additives (kaolin/mullite) forming water-insoluble $\mathrm{K}$-aluminosilicate. $\mathrm{C}_{\mathrm{K}}$ is the mass of potassium captured by $1 \mathrm{~g}$ of additive (kaolin/mullite) ( $\mathrm{g} \mathrm{K} / \mathrm{g}$ additive).

As shown in Figure 4, potassium in the reactants originated both from the salt $(\mathrm{KOH})$ and the additives (kaolin/mullite). The majority of potassium in the reactants was from $\mathrm{KOH}$, which was watersoluble (part A). The remaining potassium was from additives and it was water-insoluble (part D). During the KOH-capture reaction, a part of the water-soluble K reacted with kaolin/mullite forming water-insoluble K-aluminosilicate (part C) while the unreacted $\mathrm{KOH}$ remained water-soluble (part B). The K-conversion $\left(\mathrm{X}_{\mathrm{K}}\right)$, and $\mathrm{K}$-capture level $\left(\mathrm{C}_{\mathrm{K}}\right)$ were calculated basing on the ICP-OES analysis results of reacted samples as shown in equation 1 and 2.

$$
\begin{aligned}
X_{K} & =\frac{C}{A} \times 100 \% \\
C_{K} & =\frac{n_{K O H} M_{K} X_{K}}{m_{a d}}
\end{aligned}
$$


In equation $1, \mathrm{C}$ is the amount of water-insoluble potassium formed by the $\mathrm{K}$-capture reaction, and $\mathrm{A}$ is the amount of potassium from $\mathrm{KOH}$ fed into the reactor, as shown in Figure 4. $n_{K s a l t}(\mathrm{~mol})$ is the molar amount of $\mathrm{KOH}$ fed into the reactor, $\mathrm{M}_{\mathrm{K}}$ is the molar mass of $\mathrm{K}(\mathrm{g} / \mathrm{mol})$ and $m_{a d}$. is the mass of solid additives fed into the reactor $(\mathrm{g})$. The details of the method for quantifying K-capture can be found in Appendix II of the supplementary material.

To characterize the mineralogical composition of the reacted solid products, the collected samples were washed with deionized water at room temperature for 24 hours to remove the water-soluble compounds (i.e. the K-salts in the reactant), and then filtered using $0.4 \mu \mathrm{m}$ membranes. Subsequently, the water-washed solid samples were subjected to X-ray diffractometry (XRD) analysis. The XRD spectra were determined with a Huber diffractometer with characteristic $\mathrm{Cu} \mathrm{K} \alpha$ radiation and operation conditions of $40 \mathrm{kV}$ and $40 \mathrm{~mA}$. The wave length was $1.54056 \AA$. The identification of the main crystalline phase was performed with the JADE 6.0 software package (MDI Livermore, CA) and the diffraction database of PDF2-2004.

\subsection{Equilibrium Calculations}

To understand the transformation of $\mathrm{KOH}$ at high temperature, global equilibrium calculations at the same conditions as shown in experimental series (A) of Table 2 were conducted. To make a comparison of the experimental K-conversion relative to equilibrium, global equilibrium calculations were carried out at the conditions shown in experimental series (B-F) of Table 2. The calculations were performed using the Equilibrium module of the software FactSage 7.0. The databases of FactPS, FToxid, FTsalt and FTpulp were employed for the calculations. Information about the different databases can be found in literature. ${ }^{76,77}$ 


\section{Results and discussion}

\subsection{Evaporation and transformation of $\mathrm{KOH}$ in the EFR}

Equilibrium calculations as well as EFR experiments (experimental series (A) in Table 2) were conducted to investigate the evaporation and transformation of $\mathrm{KOH}$ at high temperatures. The mass fractions of the collected solid products in cyclone and filter are shown in Figure 5 (A). The results of corresponding equilibrium calculations are shown in Figure 5 (B).

In the EFR sampling system, the large particles were collected in the cyclone, while the aerosols were collected in the filter. When the K-salts were completely vaporized in the reactor and then cooled down in the extraction probe, aerosols would form and all solid products would be collected in the filter. If some of the salt particles generated from evaporation of slurry droplets were not fully vaporized, both aerosols and some larger particles would be present, resulting in some solid material being collected also by the cyclone. The experimental data in Figure 5(A) indicate that a complete vaporization of $\mathrm{KOH}$ was obtained at $1100^{\circ} \mathrm{C}$. At 800 and $900{ }^{\circ} \mathrm{C}$, the mass fraction of samples collected in the cyclone was $2.0 \%$ and $1.5 \%$ respectively, indicating that a small amount of $\mathrm{KOH}$ not evaporated. This is in agreement with the equilibrium calculations (Figure 5(B)), which predict that the majority of $\mathrm{KOH}$ appears as vapor at temperatures above $820^{\circ} \mathrm{C}$.

$\mathrm{XRD}$ analysis of the solid samples collected from the $\mathrm{KOH}$ evaporation experiments showed they consisted of $\mathrm{K}_{2} \mathrm{CO}_{3} \cdot 1.5 \mathrm{H}_{2} \mathrm{O}$. During cooling, gaseous or condensed $\mathrm{KOH}$ reacts with $\mathrm{CO}_{2}$ to form $\mathrm{K}_{2} \mathrm{CO}_{3}$, which then absorbs moisture from the air forming $\mathrm{K}_{2} \mathrm{CO}_{3} \cdot 1.5 \mathrm{H}_{2} \mathrm{O}$.

\subsection{Representativeness of solid product samples}

The solid products from the EFR experiments, including samples from the sampling probe, cyclone and filter, were carefully collected. For each experiment the collected solid products corresponded to 
about $58 \%$ to $75 \%$ of the theoretical amount solid samples extracted by the probe. The rest were lost, mainly by deposition on the inner wall of the reactor tube. ${ }^{78}$

Therefore, in order to be able to determine the conversion degree of the reaction based on the collected solid product samples, the representativeness of the collected solid product samples were checked. This was done by comparing the molar ratio of $\mathrm{K} /(\mathrm{Al}+\mathrm{Si})$ in the products with that of the fed reactants. The results based on ICP-OES analysis are shown in Figure 6. The molar ratios of $\mathrm{K} /(\mathrm{Al}+\mathrm{Si})$ in the collected solid samples are nearly identical to those of the reactants, implying that the solid product samples are representative.

\subsection{Evolution of kaolin in the EFR}

Slurries of normal kaolin $\left(\mathrm{D}_{50}=5.47 \mu \mathrm{m}\right)$ without and with $\mathrm{KOH}$ were fed into the EFR at $1300{ }^{\circ} \mathrm{C}$, where the residence time was $1.2 \mathrm{~s}$. XRD and SEM-EDX were utilized to study the mineralogical and morphological evolutions of kaolin during the reaction with $\mathrm{KOH}$. The XRD spectra of the raw kaolin, the dehydroxylated kaolin (i.e. product of kaolin fed into the EFR without $\mathrm{KOH}$ ), mullite, and the water-washed KOH-captured kaolin samples are compared in Figure 7.

The results show that only mullite and quartz were detected in the dehydroxylated kaolin (Figure 7 c); no kaolinite was detected. This reveals that at $1300^{\circ} \mathrm{C}$, with a residence time of $1.2 \mathrm{~s}$, all kaolinite from raw kaolin has decomposed completely. However, the peaks corresponding to mullite of the dehydroxylated kaolin are obviously weaker compared to the peaks of the mullite powder (Figure $7 \mathrm{~b}$ ). This shows that not all the decomposed kaolinite was converted to crystalline mullite with some remaining as amorphous species, like metakaolin and amorphous silica. ${ }^{59}$ In the water washed KOHreacted kaolin (Figure 7 a), crystalline kaliophilite $\left(\mathrm{KAlSiO}_{4}\right)$ was detected, as the reaction product of kaolin and $\mathrm{KOH}$ at high temperatures $\left(1300^{\circ} \mathrm{C}\right)$ in the EFR. 
The SEM images of raw kaolin, the dehydroxylated kaolin and water-washed KOH-reacted kaolin are compared in Figure 8. It is seen that raw kaolin particles are all in a form of an irregular flaky shape, while the dehydroxylated kaolin particles are slightly more spherical but keep the original inner flaky structure. The flaky structure indicates that no significant melting took place at $1300{ }^{\circ} \mathrm{C}$, in agreement with the reported mullite melting point of $1830{ }^{\circ} \mathrm{C} .{ }^{79}$ For the KOH-reacted kaolin sample, some spherical particles with smooth surface were observed, showing the particles experienced melting in the EFR. Since the kaliophilite $\left(\mathrm{KAlSiO}_{4}\right)$ detected in the $\mathrm{KOH}$-reacted solid product has a melting point of $1800{ }^{\circ} \mathrm{C},{ }^{70}$ it is mostly likely some amorphous products with low melting point were formed as well.

Water-washed KOH-reacted kaolin (Figure 8 (C)) was analyzed with SEM-EDX to get the elemental composition. The result shows that the molar ratio of $\mathrm{K}: \mathrm{Al}: \mathrm{Si}$ is $1: 1.18: 1.37$, i.e., with extra $\mathrm{Si}$ compared to the chemical formula of kaliophilite $\left(\mathrm{KAlSiO}_{4}\right)$. This is attributed to the presence of quartz $\left(\mathrm{SiO}_{2}\right)$, which was also detected with the XRD analysis. It could also be due to the formation of some amorphous Si-species, which cannot be detected by XRD analysis.

\subsection{Equilibrium calculations}

Equilibrium calculations were carried out for the same conditions as in the EFR, but with a wider temperature range from $500{ }^{\circ} \mathrm{C}$ to $1800{ }^{\circ} \mathrm{C}$. The influence of both the $\mathrm{KOH}$ concentration and thereby the molar $\mathrm{K} /(\mathrm{Al}+\mathrm{Si})$ ratio in the reactants, and the reaction temperature was studied by the calculations. A summary of the equilibrium calculation results is shown in Table 3. The detailed results of the calculations are shown in Appendix III of the supplementary material.

The results in Table 3 indicate that the main K-aluminosilicate species formed from the reaction between $\mathrm{KOH}$ and kaolin varies with the molar ratio of $\mathrm{K} /(\mathrm{Al}+\mathrm{Si})$ in the input. At $800-1450{ }^{\circ} \mathrm{C}$, with 
50 ppmv $\mathrm{KOH}$, sanidine $\left(\mathrm{KAlSi}_{3} \mathrm{O}_{8}\right)$ is the main aluminosilicate product with $\mathrm{K}: \mathrm{Al}: \mathrm{Si}=1: 1: 3$; With 250 ppmv $\mathrm{KOH}$, both sanidine $\left(\mathrm{KAlSi}_{3} \mathrm{O}_{8}\right)$ and leucite $\left(\mathrm{KAlSi}_{2} \mathrm{O}_{6}\right)$ are major K-aluminosilicates; while with 500-1000 ppmv $\mathrm{KOH}$, kaliophilite $\left(\mathrm{KAlSiO}_{4}\right)$ with $\mathrm{K}: \mathrm{Al}: \mathrm{Si}=1: 1: 1$ became the dominating $\mathrm{K}$ aluminosilicate.

\subsection{Impact of the potassium concentration}

The experimental K-capture level $\left(\mathrm{C}_{\mathrm{K}}\right)$ and $\mathrm{K}$-conversion $\left(\mathrm{X}_{\mathrm{K}}\right)$ are compared with the estimations from equilibrium calculations in Figure 9. The $\mathrm{KOH}$-concentration in the flue gas varied from 50 ppmv to 1000 ppmv, while the reaction temperature was kept constant at $1100{ }^{\circ} \mathrm{C}$. The experimental data follows a similar trend but is always slightly lower as compared to the equilibrium prediction. When the $\mathrm{KOH}$ concentration increased from $50 \mathrm{ppmv}$ to $500 \mathrm{ppmv}$, the $\mathrm{K}$-capture level $\left(\mathrm{C}_{\mathrm{K}}\right)$ by kaolin increased from $0.022 \mathrm{~g} \mathrm{~K} /$ (g kaolin) to $0.227 \mathrm{~g} \mathrm{~K} /$ (g kaolin). However, no obvious increase of $\mathrm{C}_{\mathrm{K}}$ is observed when the $\mathrm{KOH}$ concentration increased further to 750 and $1000 \mathrm{ppmv}$. This is probably because the active compound in kaolin has been fully converted into K-aluminosilicates, while the increased $\mathrm{KOH}$ remained unreacted. The equilibrium constrain can explain the decrease of $\mathrm{K}$ conversion $\left(\mathrm{X}_{\mathrm{K}}\right) . \mathrm{X}_{\mathrm{K}}$ decreased slightly from $95.8 \%$ to $84.6 \%$ when the $\mathrm{KOH}$ concentration increased from 50 ppmv to 500 ppmv, while $\mathrm{X}_{\mathrm{K}}$ decreased sharply when the $\mathrm{KOH}$ concentration increased from 500 ppmv to 1000 ppmv as shown in Figure 9 (B).

The XRD spectra of the water-washed $\mathrm{KOH}-$ reacted kaolin at 50, 250 and 500 ppmv $\mathrm{KOH}$ are compared in Figure 10. The spectra at $750 \mathrm{ppmv}$ and $1000 \mathrm{ppmv}$ were similar to that at $500 \mathrm{ppmv}$ and are not included. The results show that in the $50 \mathrm{ppmv}-\mathrm{KOH}$ product, only quartz and mullite were detected as the main crystalline phases. No crystalline K-aluminosilicate was detected in the sample, although sanidine $\left(\mathrm{KAlSi}_{3} \mathrm{O}_{8}\right)$ was predicted by the equilibrium calculations shown in Table 3 . This is 
probably because the concentration of K-aluminosilicates is low and/or they remained in an amorphous state, which cannot be detected. The $250 \mathrm{ppmv} \mathrm{KOH}$ spectrum shows that leucite $\left(\mathrm{KAlSi}_{2} \mathrm{O}_{6}\right)$ with a molar ratio of $\mathrm{K}: \mathrm{Al}: \mathrm{Si}=1: 1: 2$ was the main $\mathrm{K}$-aluminosilicate, while kaliophilite $\left(\mathrm{KAlSiO}_{4}\right)$ with a molar ratio of $\mathrm{K}: \mathrm{Al}: \mathrm{Si}=1: 1: 1$ became the main $\mathrm{K}$-aluminosilicate at $500 \mathrm{ppmv} \mathrm{KOH}$. The $\mathrm{XRD}$ analysis results generally agree with the equilibrium calculations shown in Table 3.

\subsection{Impact of reaction temperature}

The K-capture level $\left(\mathrm{C}_{\mathrm{K}}\right)$ and $\mathrm{K}$-conversion $\left(\mathrm{X}_{\mathrm{K}}\right)$ obtained at different reaction temperatures (800$1450{ }^{\circ} \mathrm{C}$ ) and two different $\mathrm{KOH}$ concentrations (50 ppmv and $500 \mathrm{ppmv}$ ) were compared with the equilibrium calculation results in Figure 11. Figure 11 (A) and (B) show that, at $500 \mathrm{ppmv} \mathrm{KOH}$, the K-capture level $\left(\mathrm{C}_{\mathrm{K}}\right)$ increased from $0.166 \mathrm{~g} \mathrm{~K} /(\mathrm{g}$ kaolin) to $0.241 \mathrm{~g} \mathrm{~K} /(\mathrm{g}$ kaolin) by $43.6 \%$, when the reaction temperature increased from $800{ }^{\circ} \mathrm{C}$ to $1300{ }^{\circ} \mathrm{C}$. The K-conversion $\left(\mathrm{X}_{\mathrm{K}}\right)$ increased from $62.1 \%$ to $89.1 \%$, correspondingly. However, when the temperature was increased further to $1450{ }^{\circ} \mathrm{C}, \mathrm{C}_{\mathrm{K}}$ and $\mathrm{X}_{\mathrm{K}}$ decreased to $0.198 \mathrm{~g} \mathrm{~K} /(\mathrm{g}$ kaolin) and $74.0 \%$ respectively. This is caused by a change in the equilibrium products with a decreased amount of kaliophilite $\left(\mathrm{KAlSiO}_{4}\right)$ and an increased amount of leucite $\left(\mathrm{KAlSi}_{2} \mathrm{O}_{6}\right)$ at high temperatures. At $1300{ }^{\circ} \mathrm{C}$ and $1450{ }^{\circ} \mathrm{C}$, the $\mathrm{K}$-capture level $\left(\mathrm{C}_{\mathrm{K}}\right)$ is close to the equilibrium calculation value. At $1100{ }^{\circ} \mathrm{C}$ and below, the $\mathrm{K}$-capture levels $\left(\mathrm{C}_{\mathrm{K}}\right)$ are below the equilibrium levels, implying the process is kinetic controlled.

Figure $11(\mathrm{C})$ and $(\mathrm{D})$ show that at $50 \mathrm{ppmv} \mathrm{KOH}$, the $\mathrm{K}$-capture level $\left(\mathrm{C}_{\mathrm{K}}\right)$ was predicted to be $0.023 \mathrm{~g} \mathrm{~K} / \mathrm{g}$ kaolin, by the equilibrium calculations, and the predicted $\mathrm{K}$-conversion $\left(\mathrm{X}_{\mathrm{K}}\right)$ was higher than $99.2 \%$ through the whole temperature range. At temperatures above $1100{ }^{\circ} \mathrm{C}$, the experimental $\mathrm{C}_{\mathrm{K}}$ and $\mathrm{X}_{\mathrm{K}}$ were close to the equilibrium calculations. At $800{ }^{\circ} \mathrm{C}$ and $900{ }^{\circ} \mathrm{C}$, the experimental result is 
slightly lower than the value predicted by the equilibrium calculations. The only K-aluminosilicate predicted by the calculations is sanidine $\left(\mathrm{KAlSi}_{3} \mathrm{O}_{8}\right)$ with a molar ratio of $\mathrm{K}: \mathrm{Al}: \mathrm{Si}=1: 1: 3$.

The water-washed 500 ppmv KOH-reacted kaolin samples were subjected to XRD analysis, with the spectra shown in Figure 12. It shows that with the temperature increased from 800 to $1450{ }^{\circ} \mathrm{C}$, the peaks of kaliophilite $\left(\mathrm{KAlSiO}_{4}\right)$ increased significantly, indicating either kaliophilite was generated in larger quantities or that it became more crystalline with the increasing temperature or due to a faster cooling rate in the sampling system. No other crystalline K-aluminosilicate product was detected, although leucite $\left(\mathrm{KAlSi}_{2} \mathrm{O}_{6}\right)$ was also predicted by the equilibrium calculations. The formation of kaliophilite was also observed in experimental studies by Steenari and her co-workers. ${ }^{45}$ Kalsilite $\left(\mathrm{KAlSiO}_{4}\right)$, a polymorph of kaliophilite was also widely reported in previous studies. ${ }^{51,70,72,80}$ At $800{ }^{\circ} \mathrm{C}$ and $900{ }^{\circ} \mathrm{C}$, no clear signal of $\mathrm{K}$-aluminosilicate was detected by XRD. This is probably because the formed K-aluminosilicate existed in an amorphous form at lower temperatures. Kaolinite was detected in the 800 and $900{ }^{\circ} \mathrm{C}$ solid products, indicating an incomplete dehydroxylation of kaolin at temperatures below $900{ }^{\circ} \mathrm{C}$ in the EFR.

\subsection{Impact of gas residence time}

The impact of gas residence time on the $\mathrm{KOH}$-capture reaction was investigated at $800{ }^{\circ} \mathrm{C}$ and $1100{ }^{\circ} \mathrm{C}$. At $800{ }^{\circ} \mathrm{C}$, the gas residence time varied from $1.2 \mathrm{~s}$ to $1.9 \mathrm{~s}$, while at $1100^{\circ} \mathrm{C}$, it was changed from $0.7 \mathrm{~s}$ to $1.7 \mathrm{~s}$. In all experiments, the $\mathrm{KOH}$-concentration in the flue gas and the molar ratio of $\mathrm{K} /(\mathrm{Al}+\mathrm{Si})$ in the reactants were kept constant, at $500 \mathrm{ppmv}$ and 0.481 , respectively. The experimental results were compared to the equilibrium calculation results in Figure 13.

At $800{ }^{\circ} \mathrm{C}$, as shown in Figure 13 (A), when the gas residence time increased from $1.2 \mathrm{~s}$ to $1.9 \mathrm{~s}, \mathrm{~K}$ capture level $\left(\mathrm{C}_{\mathrm{K}}\right)$ increases by $25.4 \%$ from $0.166 \mathrm{~g} \mathrm{~K} / \mathrm{g}$ kaolin to $0.209 \mathrm{~g} \mathrm{~K} / \mathrm{g}$ kaolin. However at 
$1100{ }^{\circ} \mathrm{C}$, when the gas residence time increased from $0.7 \mathrm{~s}$ to $1.2 \mathrm{~s}, \mathrm{C}_{\mathrm{K}}$ increased by $7.6 \%$, from 0.211 to $0.227 \mathrm{~g} \mathrm{~K} / \mathrm{g}$ kaolin. When the gas residence time increased further from $1.2 \mathrm{~s}$ to $1.7 \mathrm{~s}, \mathrm{C}_{\mathrm{K}}$ increased to 0.236 by $4.1 \%$.

In summary, the $\mathrm{KOH}$-capture reaction by kaolin reached equilibrium at temperatures of $1300{ }^{\circ} \mathrm{C}$ and $1450{ }^{\circ} \mathrm{C}$, with a gas residence time of $1.2 \mathrm{~s}$ and a kaolin particle size of $\mathrm{D}_{50}=5.47 \mu \mathrm{m}$. At $1100{ }^{\circ} \mathrm{C}$ with a residence time of $1.7 \mathrm{~s}$, the reaction is close to the equilibrium. However, at $800{ }^{\circ} \mathrm{C}, \mathrm{C}_{\mathrm{K}}$ is obviously further away from the equilibrium even with a longer residence time of $1.9 \mathrm{~s}$, showing that the reaction is more kinetically or diffusion controlled at $800{ }^{\circ} \mathrm{C}$.

\subsection{Impact of kaolin particle size}

The K-capture level $\left(\mathrm{C}_{\mathrm{K}}\right)$ of fine kaolin, normal kaolin and coarse kaolin at $800-1450{ }^{\circ} \mathrm{C}$ were compared to the equilibrium calculation results in Figure 14. Generally, the results show that at 900$1300{ }^{\circ} \mathrm{C}$ fine kaolin and normal kaolin behaved similarly, and $\mathrm{C}_{\mathrm{K}}$ did not increase when the $\mathrm{D}_{50}$ of kaolin particle size decreased from $5.47 \mu \mathrm{m}$ to $3.51 \mu \mathrm{m}$. For coarse kaolin, $\mathrm{C}_{\mathrm{K}}$ is similar as that of normal and fine kaolin at $900{ }^{\circ} \mathrm{C}$. However it became lower than the $\mathrm{C}_{\mathrm{K}}$ of normal and fine kaolin at 1100 and $1300{ }^{\circ} \mathrm{C}$. This indicates that the conversion at 1100 and $1300{ }^{\circ} \mathrm{C}$ is partly limited by the transport processes, at least for the coarse kaolin. However, at $800{ }^{\circ} \mathrm{C}$ the reaction appears to be kinetically limited.

\subsection{KOH capture by mullite}

The KOH capture level of mullite $\left(\mathrm{D}_{50}=5.90 \mu \mathrm{m}\right)$ was compared with that of normal kaolin $\left(\mathrm{D}_{50}=\right.$ $5.47 \mu \mathrm{m}$ ) in Figure 15, at reaction temperatures of $800-1450{ }^{\circ} \mathrm{C}$, gas residence time of $1.2 \mathrm{~s}$ and a $\mathrm{KOH}$ concentration of 500 ppmv. The EFR experimental results show, that at low temperatures (800 $\left.1100{ }^{\circ} \mathrm{C}\right), \mathrm{C}_{\mathrm{K}}$ of mullite is much lower than that of kaolin. This is probably partly because the BET 
surface area of mullite is smaller than that of kaolin (shown in Table 1) and thereby limited the internal $\mathrm{KOH}$ transport in the particles. On the other hand, the kinetics of the mullite- $\mathrm{KOH}$ reaction is probably slower than that of the kaolin- $\mathrm{KOH}$ reaction. At $1300{ }^{\circ} \mathrm{C}$ and $1450{ }^{\circ} \mathrm{C}, \mathrm{C}_{\mathrm{K}}$ of mullite increased significantly, and at $1450{ }^{\circ} \mathrm{C}$, the value is close to that of the normal kaolin powder. This is probably because at high temperatures $\left(1300\right.$ and $\left.1450{ }^{\circ} \mathrm{C}\right)$, the $\mathrm{KOH}-$ reacted mullite particles are melted, and the $\mathrm{KOH}$ diffusion mechanism changed from a slow gas-solid diffusion to a faster gas-liquid diffusion which improved the transport of $\mathrm{KOH}$ inside the mullite particles. A similar phenomenon was observed by Zheng et al., when the $\mathrm{KCl}$ capture by mullite pellets was studied in a fixed bed reactor. ${ }^{52}$

\section{Conclusions}

The impact of different parameters, including the potassium concentration in flue gas (molar ratio of $\mathrm{K} /(\mathrm{Al}+\mathrm{Si})$ in reactants $)$, the reaction temperature, the residence time, the kaolin particle size, as well as the high temperatures phase transformations of kaolin, on the $\mathrm{KOH}$-capture reaction at suspension fired conditions was investigated, by experiments in an entrained flow reactor and by thermodynamic equilibrium calculations.

The K-capture level $\left(\mathrm{C}_{\mathrm{K}}\right)$ increased significantly when the $\mathrm{KOH}$-concentration increased from 50 to 500 ppmv, corresponding to an increase in the molar $\mathrm{K} /(\mathrm{Al}+\mathrm{Si})$ ratio from 0.048 to 0.48 , whereas no obvious increase was observed when $\mathrm{KOH}$-concentration increased further to $750 \mathrm{ppmv}$ and 1000 ppmv. Leucite $\left(\mathrm{KAlSi}_{2} \mathrm{O}_{6}\right)$ was formed at $250 \mathrm{ppmv} \mathrm{KOH}(\mathrm{K} /(\mathrm{Al}+\mathrm{Si})=0.240)$, and kaliophilite $\left(\mathrm{KAlSiO}_{4}\right)$ was the dominant $\mathrm{K}$-aluminosilicate at $500 \mathrm{ppmv} \mathrm{KOH}$ and above $(\mathrm{K} /(\mathrm{Al}+\mathrm{Si}) \geq 0.481)$.

A nearly full conversion of kaolin $\left(\mathrm{D}_{50}=5.47 \mu \mathrm{m}\right)$ was obtained without kinetic or transport limitations at temperatures above $1100{ }^{\circ} \mathrm{C}$ and the applied conditions (residence time of $1.2 \mathrm{~s}$, and a 
$\mathrm{KOH}$ concentration of $500 \mathrm{ppmv})$. However, at 800 and $900{ }^{\circ} \mathrm{C}$, the experimental data were considerably lower than the equilibrium predictions, and the K-capture level increased significantly when residence time increased, implying the reaction is probably kinetically controlled. The optimal temperature window for injecting kaolin for K-capture at suspension-fired conditions is $1100-1300{ }^{\circ} \mathrm{C}$. At $1100{ }^{\circ} \mathrm{C}$ or above, crystalline kaliophilite $\left(\mathrm{KAlSiO}_{4}\right)$ was detected by XRD analysis, while at 800 and $900{ }^{\circ} \mathrm{C}$, amorphous $\mathrm{K}$-aluminosilicate was formed.

Fine kaolin powder $\left(D_{50}=3.51 \mu \mathrm{m}\right)$ and normal kaolin powder $\left(\mathrm{D}_{50}=5.47 \mu \mathrm{m}\right)$ behaved similarly in terms of K-capture level $\left(\mathrm{C}_{\mathrm{K}}\right)$, while coarse kaolin $\left(\mathrm{D}_{50}=13.48 \mu \mathrm{m}\right)$ showed a considerably smaller $\mathrm{K}$ capture level at 1100 and $1300{ }^{\circ} \mathrm{C}$. This is probably because $\mathrm{KOH}$ diffusion into the kaolin particles became a limiting factor for the coarse kaolin at $1100{ }^{\circ} \mathrm{C}$ and above. At $900{ }^{\circ} \mathrm{C}$, where the difference was smaller, the reaction is more kinetically controlled and the additive particle size did not influence the reaction significantly with the applied particle sizes.

Mullite captured $\mathrm{KOH}$ less effectively compared to kaolin at temperatures below $1100{ }^{\circ} \mathrm{C}$. However $\mathrm{C}_{\mathrm{K}}$ of mullite increased significantly at $1300{ }^{\circ} \mathrm{C}$ and $1450{ }^{\circ} \mathrm{C}$. At $1450{ }^{\circ} \mathrm{C}$, the K-capture level of mullite is comparable to that of kaolin.

\section{Acknowledgements}

This work is part of the project 'Flexible use of Biomass on PF fired power plants' funded by Energinet.dk through the ForskEL programme, Ørsted Bioenergy \& Thermal Power A/S and DTU.

Supporting Information. Appendix I of the supporting information: More detailed experimental conditions about the EFR experiments; Appendix II of the supporting information: The details of the quantification method of K-capture level $\left(\mathrm{C}_{\mathrm{K}}\right)$ and $\mathrm{K}$-conversion $\left(\mathrm{X}_{\mathrm{K}}\right)$; Appendix III of the supporting 
information: Complete results of the equilibrium calculations of $\mathrm{KOH}$ capture by normal kaolin $\left(\mathrm{D}_{50}=\right.$ $5.47 \mu \mathrm{m})$ 


\section{References}

(1) Hupa, M. Energy Fuels 2012, 26, 4-14.

(2) Wu, H.; Glarborg, P.; Frandsen, F. J.; Dam-Johansen, K.; Jensen, P. A. Energy Fuels 2011, 25, 2862-2873.

(3) Frandsen, F. J. Ash Formation, Deposition and Corrosion When Utilizing Straw for Heat and Power Production. Doctoral Thesis, Technical University of Denmark, 2011.

(4) Andersen, K. H.; Frandsen, F. J.; Hansen, P. F. B.; Wieck-Hansen, K.; Rasmussen, I.; Overgaard, P.; Dam-Johansen, K. Energy Fuels 2000, 14, 765-780.

(5) Bashir, M. S.; Jensen, P. A.; Frandsen, F. J.; Wedel, S.; Dam-johansen, K.; Wadenba, J.; Pedersen, S. T. Energy Fuels 2012.

(6) Hansen, L. A.; Nielsen, H. P.; Frandsen, F. J.; Dam-Johansen, K.; Hørlyck, S.; Karlsson, A. Fuel Process. Technol. 2000, 64, 189-209.

(7) Wang, G.; Shen, L.; Sheng, C. Energy Fuels 2012, 26, 102-111.

(8) Gao, X.; Yani, S.; Wu, H. Energy Fuels 2015, 29, 5171-5175.

(9) Niu, Y.; Zhu, Y.; Tan, H.; Hui, S.; Jing, Z.; Xu, W. Fuel Process. Technol. 2014, 128, 499-508.

(10) Skrifvars, B.-J.; Laurén, T.; Hupa, M.; Korbee, R.; Ljung, P. Fuel 2004, 83, 1371-1379.

(11) Wang, Q.; Yao, H.; Yu, D.; Dai, L.; Xu, M. Energy Fuels 2007, 21, 513-516.

(12) Laxminarayan, Y.; Jensen, P. A.; Wu, H.; Frandsen, F. J.; Sander, B.; Glarborg, P. Energy Fuels 2017, 31, 8733-8741.

(13) Kling, A.; Andersson, C.; Myringer, A.; Eskilsson, D.; Jaras, S. Appl. Catal., B: Environ. 2007, 69, 240-251.

(14) Zheng, Y.; Jensen, A. D.; Johnsson, J. E. Appl. Catal., B: Environ. 2005, 60, 253-264.

(15) Zheng, Y.; Jensen, A. D.; Johnsson, J. E.; Thøgersen, J. R. Appl. Catal., B: Environ. 2008, 83, 186-194.

(16) Zheng, Y.; Jensen, A. D.; Johnsson, J. E. Ind. Eng. Chem. Res. 2004, 43, 941-947.

(17) Kling, Å.; Andersson, C.; Myringer, Å.; Eskilsson, D.; Järås, S. G. Appl. Catal., B: Environ. 2007, 69, 240-251.

(18) Castellino, F.; Jensen, A. D.; Johnsson, J. E.; Fehrmann, R. Appl. Catal., B: Environ. 2009, 86, 206-215.

(19) Dayton, D. C.; French, R. J.; Milne, T. A. Energy Fuels 1995, 9, 855-865.

(20) Knudsen, J. N.; Jensen, P. A.; Dam-Johansen, K. Energy Fuels 2004, 18, 1385-1399.

(21) Frandsen, F. J. Fuel 2005, 84, 1277-1294.

(22) Nielsen, H. P.; Frandsen, F. J.; Dam-Johansen, K. Energy Fuels 1999, 13, 1114-1121.

(23) Tobiasen, L.; Skytte, R.; Pedersen, L. S.; Pedersen, S. T.; Lindberg, M. A. Fuel Process. Technol. 2007, 88, 1108-1117.

(24) Kassman, H.; Pettersson, J.; Steenari, B.-M.; Åmand, L.-E. Fuel Process. Technol. 2013, 105, 170-180.

(25) Davidsson, K. O.; Åmand, L. E.; Steenari, B. M.; Elled, A. L.; Eskilsson, D.; Leckner, B. Chem. Eng. Sci. 2008, 63, 5314-5329.

(26) De Fusco, L.; Boucquey, A.; Blondeau, J.; Jeanmart, H.; Contino, F. Fuel 2016, 170, 16-26.

(27) Wang, L.; Skjevrak, G.; Hustad, J. E.; Grønli, M.; Skreiberg, Ø. Energy Procedia 2012.

(28) Kyi, S.; Chadwick, B. L. Fuel 1999, 78, 845-855. 
(29) Damoe, A. J.; Wu, H.; Frandsen, F. J.; Glarborg, P.; Sander, B. Energy Fuels 2014, 28, 32173223.

(30) Boström, D.; Grimm, A.; Boman, C.; Björnbom, E.; Öhman, M. Energy Fuels 2009, 23, 51845190.

(31) Sami, M.; Annamalai, K.; Wooldridge, M. Prog. Energy Combust. Sci. 2001, 27, 171-214.

(32) Wu, H.; Glarborg, P.; Frandsen, F. J.; Dam-Johansen, K.; Jensen, P. A.; Sander, B. Fuel Process. Technol. 2013, 105, 212-221.

(33) Wu, H.; Glarborg, P.; Frandsen, F. J.; Dam-Johansen, K.; Jensen, P. A.; Sander, B. Fuel 2011, 90, 1980-1991.

(34) Savolainen, K. Appl. Energy 2003, 74, 369-381.

(35) Wu, H. Co-combustion of Fossil Fuels and Waste. Ph.D. Thesis, Technical University of Denmark, 2011.

(36) Yin, C.; Rosendahl, L. A.; Kær, S. K. Prog. Energy Combust. Sci. 2008, 34, 725-754.

(37) Jensen, P. A.; Sander, B.; Dam-Johansen, K. Biomass Bioenergy 2001, 20, 431-446.

(38) Llorente, M. J. F.; Arocas, P. D.; Nebot, L. G.; García, J. E. C. Fuel 2008, 87, 2651-2658.

(39) Si, J.; Liu, X.; Xu, M.; Sheng, L.; Zhou, Z.; Wang, C.; Zhang, Y.; Seo, Y.-C. Appl. Energy 2014, 114, 434-444.

(40) Wu, H.; Bashir, M. S.; Jensen, P. A.; Sander, B.; Glarborg, P. Fuel 2013, 113, 632-643.

(41) Wu, H.; Pedersen, M. N.; Jespersen, J. B.; Aho, M.; Roppo, J.; Frandsen, F. J.; Glarborg, P. Energy Fuels 2014, 28, 199-207.

(42) Aho, M.; Vainikka, P.; Taipale, R.; Yrjas, P. Fuel 2008, 87, 647-654.

(43) Wibberley, L. J.; Wall, T. F. Fuel 1982, 61, 93-99.

(44) Bäfver, L. S.; Rönnbäck, M.; Leckner, B.; Claesson, F.; Tullin, C. Fuel Process. Technol. 2009, 90, 353-359.

(45) Steenari, B. M.; Lindqvist, O. Biomass Bioenergy 1998, 14, 67-76.

(46) Wang, L.; Skreiberg, Ø.; Becidan, M. Appl. Therm. Eng. 2014, 70, 1262-1269.

(47) Aho, M.; Paakkinen, K.; Taipale, R. Fuel 2013, 103, 562-569.

(48) Wang, L.; Hustad, J. E.; Skreiberg, Ø.; Skjevrak, G.; Grønli, M. Energy Procedia 2012, 20, 2029.

(49) Wang, L.; Skjevrak, G.; Hustad, J. E.; Skreiberg, Ø. Energy Fuels 2014, 28, 208-218.

(50) Turn, S. Q.; Kinoshita, C. M.; Ishimura, D. M.; Zhou, J.; Hiraki, T. T.; Masutani, S. M. J. Inst. Energy 1999, 71, 163-177.

(51) Tran, K.-Q.; Iisa, K.; Steenari, B.-M.; Lindqvist, O. Fuel 2005, 84, 169-175.

(52) Zheng, Y.; Jensen, P. A.; Jensen, A. D. Fuel 2008, 87, 3304-3312.

(53) De Fusco, L.; Defoort, F.; Rajczyk, R.; Jeanmart, H.; Blondeau, J.; Contino, F. Energy Fuels 2016, 30, 8304-8315.

(54) Öhman, M.; Boström, D.; Nordin, A.; Hedman, H. Energy Fuels 2004, 18, 1370-1376.

(55) Aho, M.; Silvennoinen, J. Fuel 2004, 83, 1299-1305.

(56) Ahmaruzzaman, M. Prog. Energy Combust. Sci. 2010, 36, 327-363.

(57) Chen, Y.; Wang, G.; Sheng, C. Energy Fuels 2013.

(58) Aho, M. Fuel 2001, 80, 1943-1951.

(59) Chen, C. Y.; Lan, G. S.; Tuan, W. H. Ceram. Int. 2000, 26, 715-720.

(60) Shadman, F.; Punjak, W. A. Thermochim. Acta 1988, 131, 141-152.

(61) Uberoi, M.; Punjak, W. A.; Shadman, F. Prog. Energy Combust. Sci. 1990, 16, 205-211.

(62) Escobar, I.; Oleschko, H.; Wolf, K.-J.; Müller, M. Powder Technol. 2008, 180, 51-56. 
(63) Mwabe, P. O.; Wendt, J. O. L. Mechanisms governing trace sodium capture by kaolinite in a downflow combustor, In 26th Symposium on Combustion, Napoli Italy, 1996.

(64) Vuthaluru, H. B.; Vleeskens, J. M.; Wall, T. F. Fuel Process. Technol. 1998, 55, 161-173.

(65) Li, M.; Zhang, Z.; Wu, X.; Fan, J. Energy Fuels 2016, 30, 7763-7769.

(66) Chen, Y.; Xu, Y.; Sheng, C. Proc. CSEE 2016, 36, 4396-4410.

(67) Niu, Y.; Tan, H.; Hui, S. e. Prog. Energy Combust. Sci. 2016, 52, 1-61.

(68) Wei, X.; Schnell, U.; Hein, K. Fuel 2005, 84, 841-848.

(69) Michelsen, H. P. Deposition and high-temperature corrosion in biomass-fired boilers. Ph.D. Thesis, Technical University of Denmark, 1998.

(70) Mwabe, P. O. Mechanisms governing alkali metal capture by kaolinite in a downflow combustor. Ph.D. Thesis, The University of Arizona, 1993.

(71) Gale, T. K.; Wendt, J. O. L. Combust. Flame 2002, 131, 299-307.

(72) Tran, K.-Q.; Iisa, K.; Hagström, M.; Steenari, B.-M.; Lindqvist, O.; Pettersson, J. B. C. Fuel 2004, 83, 807-812.

(73) Tran, Q. K.; Steenari, B.-M.; Iisa, K.; Lindqvist, O. Energy Fuels 2004, 18, 1870-1876.

(74) Zheng, Y.; Jensen, P. A.; Jensen, A. D. Potassium capture by kaolin and fly ash powder in an entrained flow reactor, Technical University of Denmark: Denmark, 2008, 1-51.

(75) Iisa, K.; Lu, Y.; Salmenoja, K. Energy Fuels 1999, 13, 1184-1190.

(76) Bale, C. W.; Chartrand, P.; Degterov, S. A.; Eriksson, G.; Hack, K.; Ben Mahfoud, R.; Melançon, J.; Pelton, A. D.; Petersen, S. Calphad. 2002, 26, 189-228.

(77) Bale, C. W.; Bélisle, E.; Chartrand, P.; Decterov, S. A.; Eriksson, G.; Hack, K.; Jung, I. H.; Kang, Y. B.; Melançon, J.; Pelton, A. D.; Robelin, C.; Petersen, S. Calphad. 2009, 33, 295-311.

(78) Theis, M.; Mueller, C.; Skrifvars, B.-J.; Hupa, M.; Tran, H. Fuel 2006, 85, 1970-1978.

(79) Schneider, H.; Schreuer, J.; Hildmann, B. J. Eur. Ceram. Soc. 2008, 28, 329-344.

(80) Punjak, W. A.; Shadman, F. Energy Fuels 1988, 2, 702-708. 


\section{FIGURES}

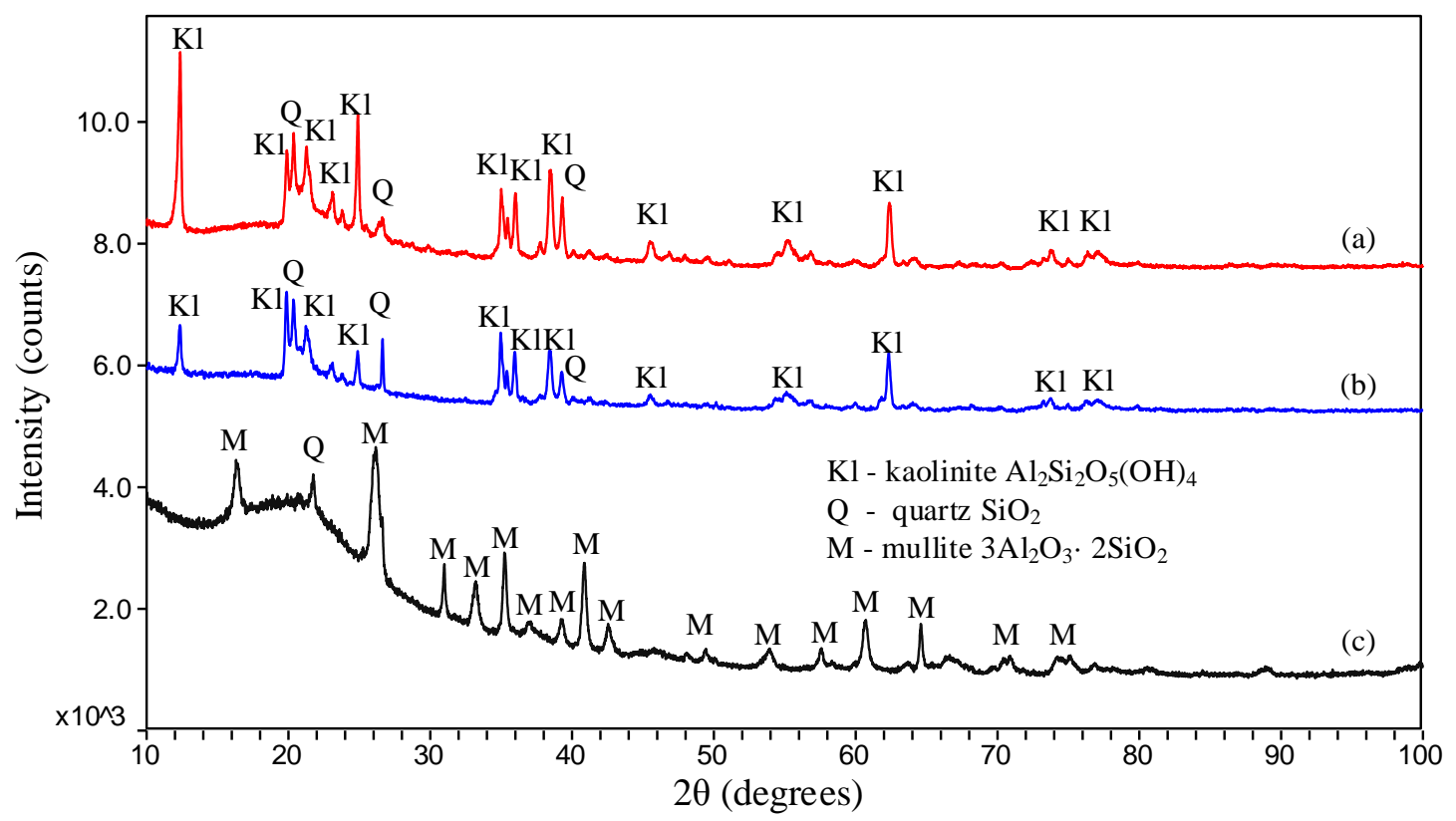

Figure 1. XRD spectra of the kaolin and mullite: normal kaolin with $\mathrm{D}_{50}=5.47 \mu \mathrm{m}$ (a); coarse kaolin with $\mathrm{D}_{50}=13.48 \mu \mathrm{m}(\mathrm{b})$; mullite (c). 


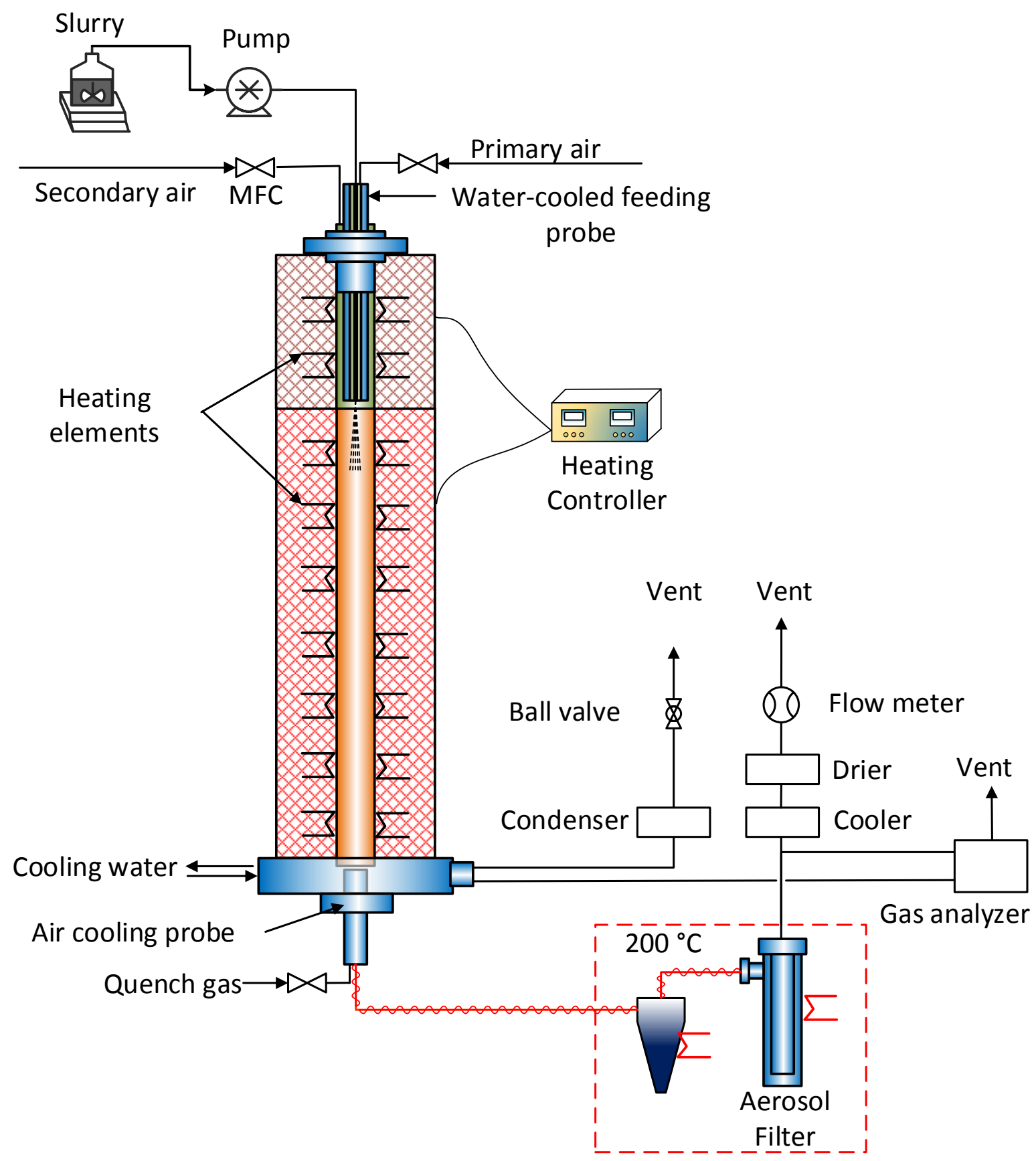

Figure 2. Schematic of the Entrained Flow Reactor (EFR). 


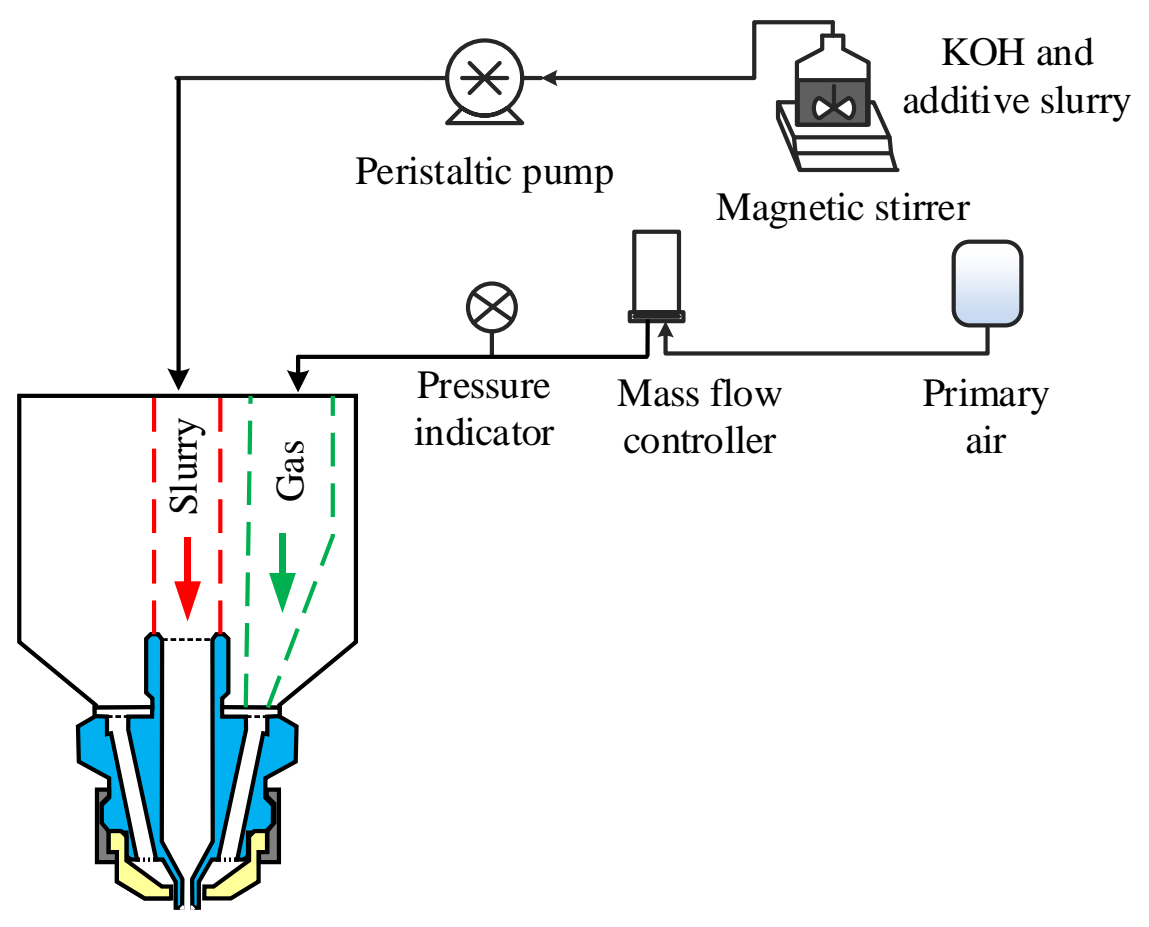

Figure 3. Slurry feeding and atomizing system of the DTU Entrained Flow Reactor (EFR).

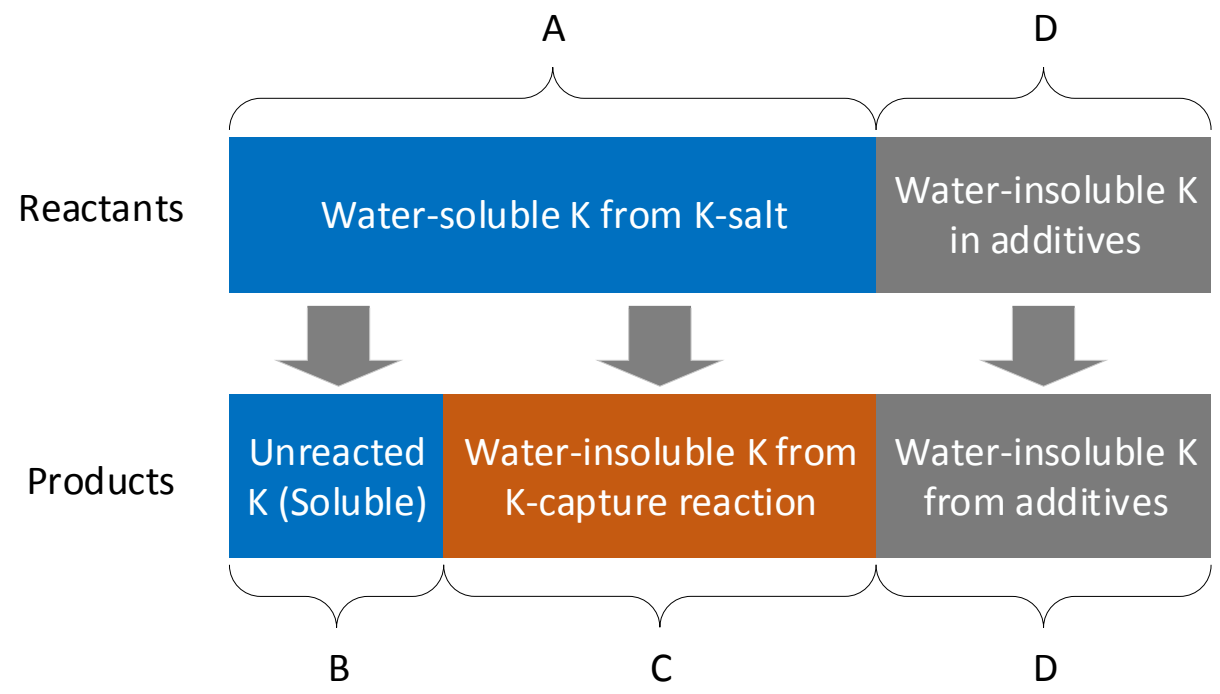

Figure 4. Potassium transformations in the K-capture reaction. 


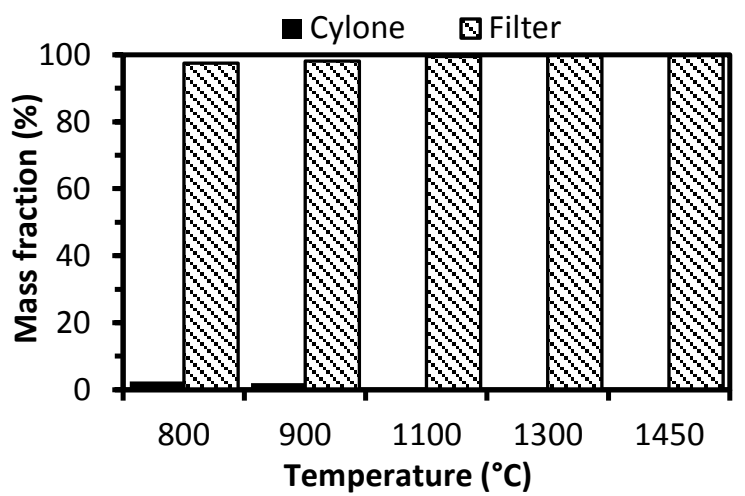

(A) EFR experiments

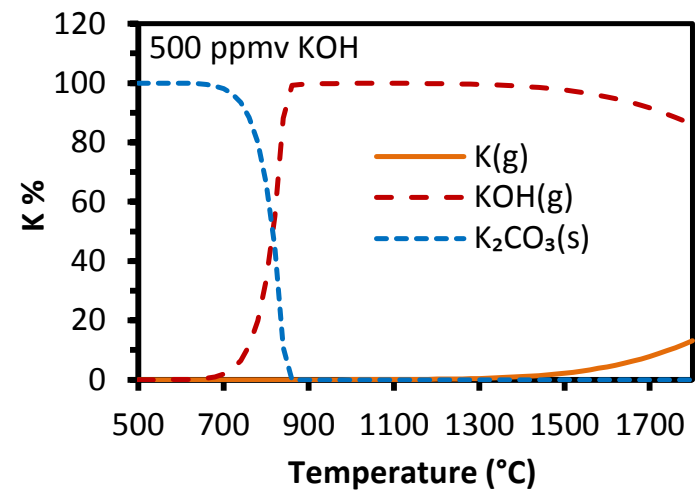

(B) Equilibrium calculation

Figure 5. Mass distribution of solid samples collected in cyclone and filter from $\mathrm{KOH}$ evaporation experiments (A); Equilibrium calculation results of $\mathrm{KOH}$ evaporation under conditions of experimental series A of Table 2 (B).

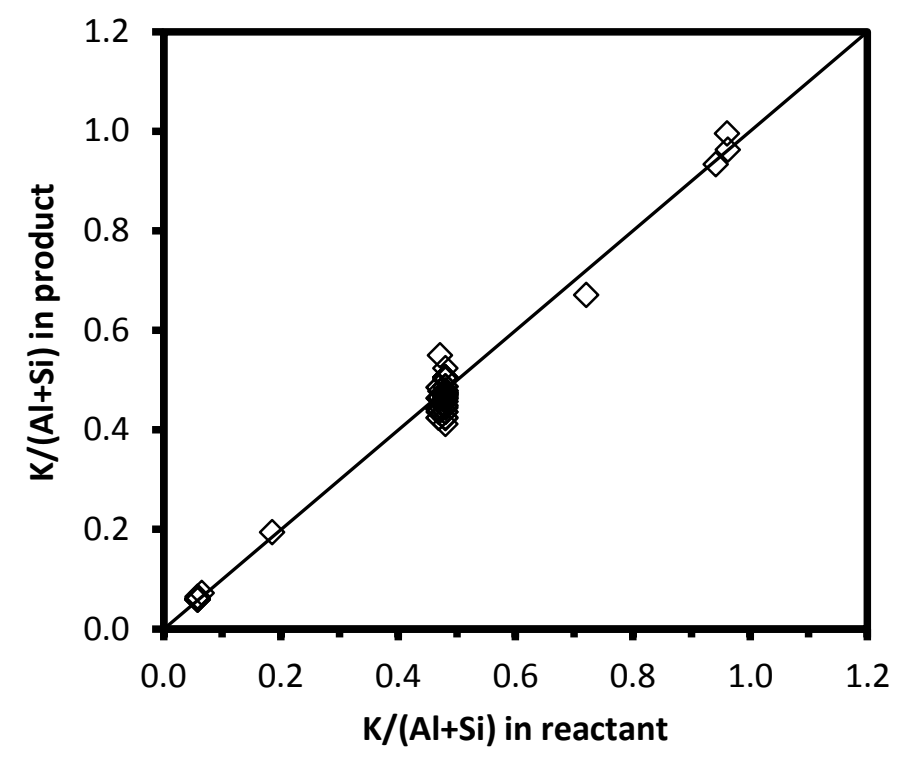

Figure 6. Comparison of $\mathrm{K} /(\mathrm{Al}+\mathrm{Si})$ in collected solid products and that of fed reactants. 


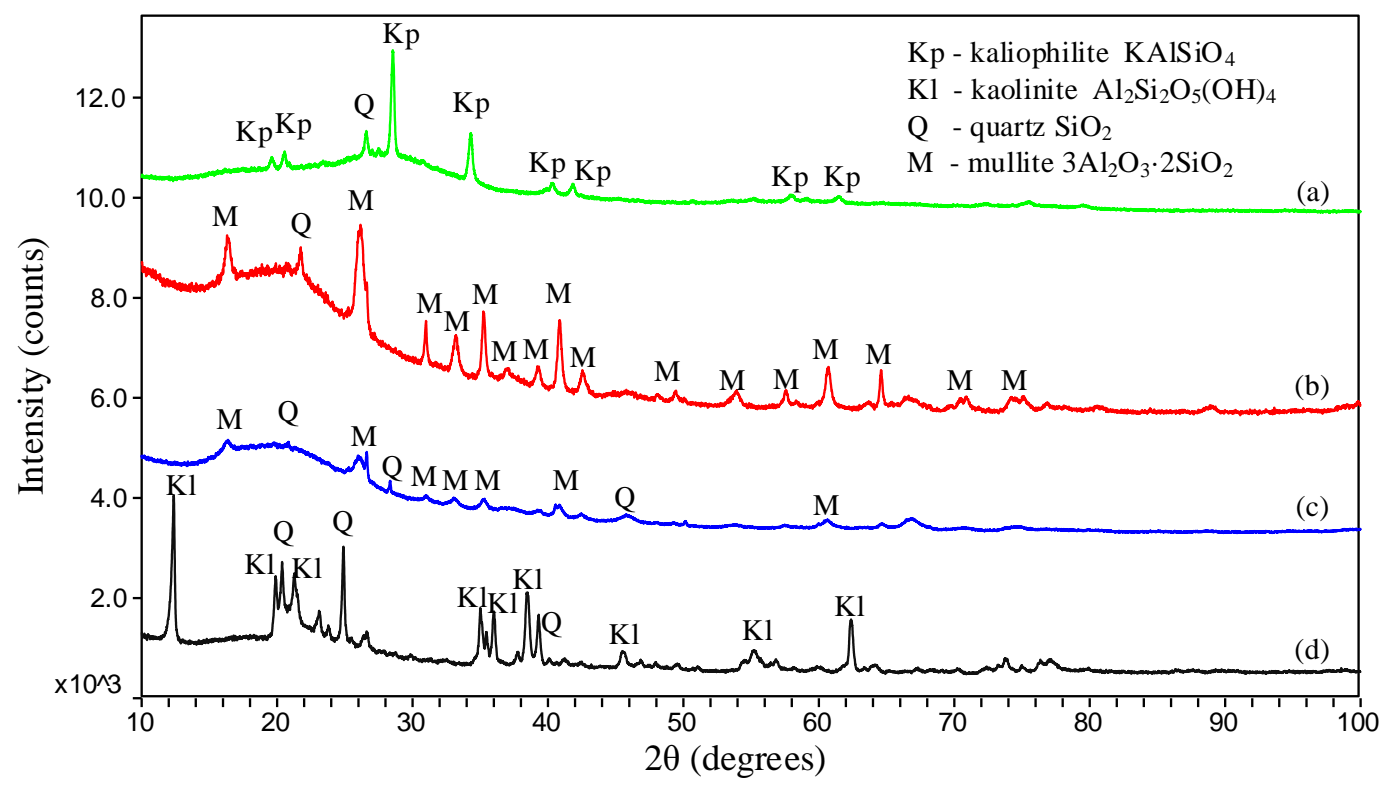

Figure 7. XRD spectra of water-washed kaolin after reaction with 500 ppmv KOH. KOH-reacted kaolin (a); mullite (1100 ${ }^{\circ} \mathrm{C}, 24$ hours) (b); dehydroxylated kaolin (c); and raw kaolin (d). For sample (a) and (c), reaction temperature in the EFR was $1300{ }^{\circ} \mathrm{C}$, and the gas residence time was $1.2 \mathrm{~s}$. 


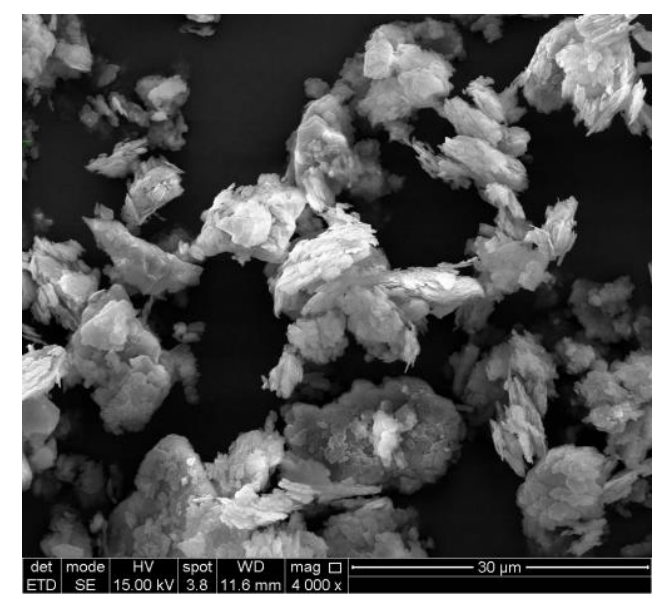

(A) Raw kaolin

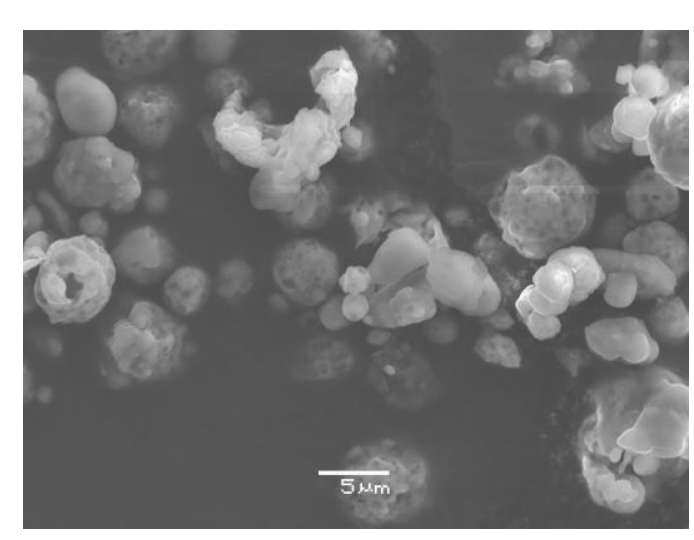

(C) $\mathrm{KOH}-$ reacted kaolin

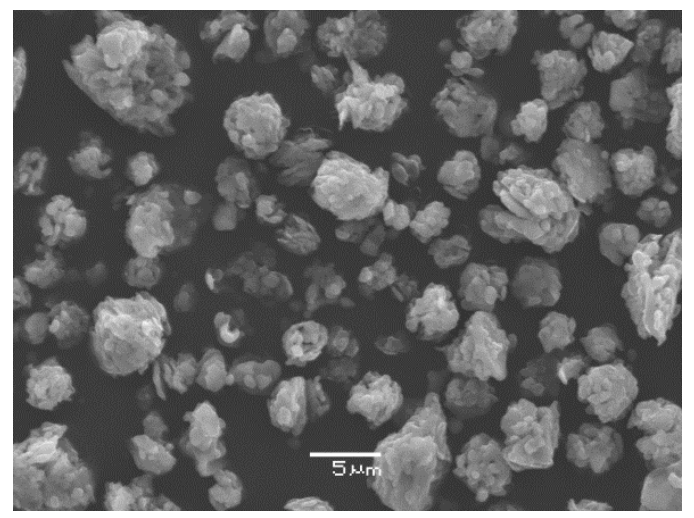

(B) Dehydroxylated kaolin

Figure 8. SEM images of raw kaolin (A); dehydroxylated kaolin (without $\mathrm{KOH}$ fed at $1300{ }^{\circ} \mathrm{C}$, residence time was $1.2 \mathrm{~s}$ ) (B); and water-washed $\mathrm{KOH}-$ reacted kaolin (C) (500 ppmv $\mathrm{KOH}$ by kaolin at $1300^{\circ} \mathrm{C}$, residence time was $1.2 \mathrm{~s}, \mathrm{~K} /(\mathrm{Al}+\mathrm{Si})$ in reactant is 0.481$)$. 


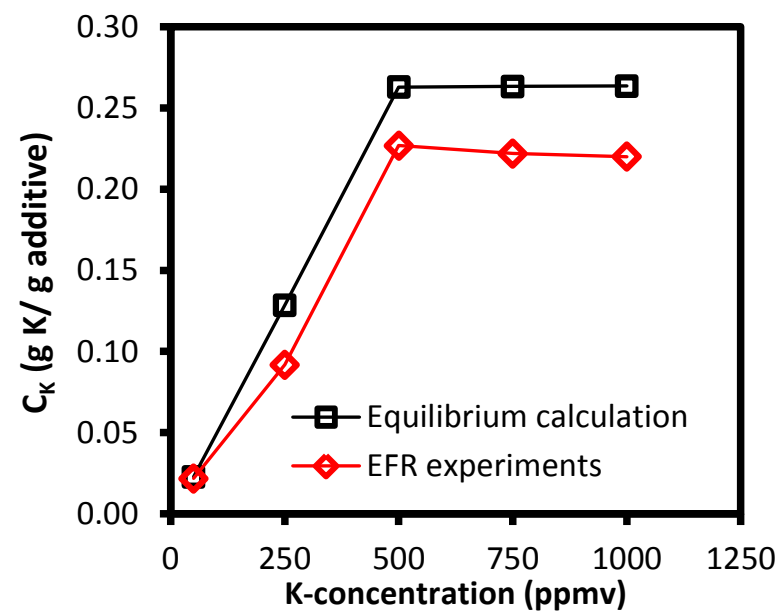

(A) $\mathrm{K}$-capture level $\left(\mathrm{C}_{\mathrm{K}}\right)$

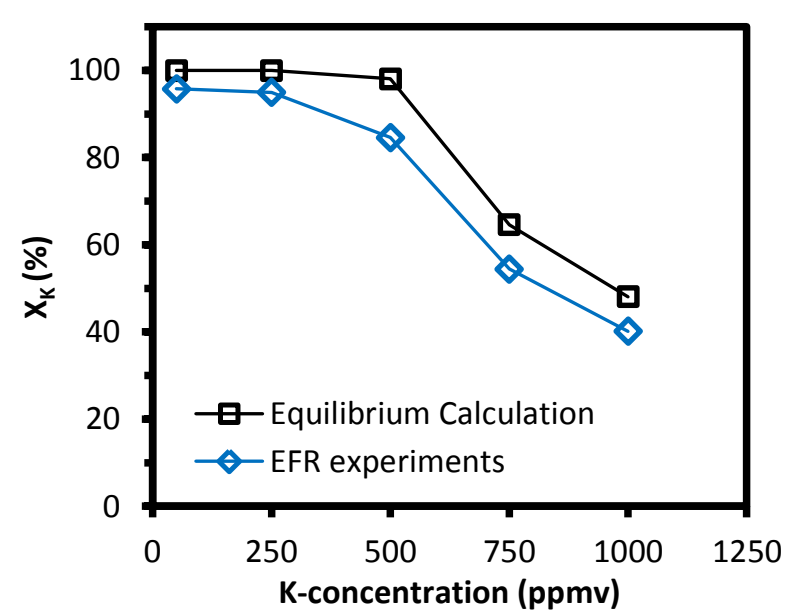

(B) K-conversion $\left(\mathrm{X}_{\mathrm{K}}\right)$

Figure 9. K-capture level $\left(\mathrm{C}_{\mathrm{K}}\right)$ and $\mathrm{K}$-conversion $\left(\mathrm{X}_{\mathrm{K}}\right)$ of $\mathrm{KOH}$-capture by normal kaolin $\left(\mathrm{D}_{50}=\right.$ $5.47 \mu \mathrm{m})$ at different $\mathrm{KOH}$ concentrations from $50 \mathrm{ppmv}$ to $1000 \mathrm{ppmv}($ molar $\mathrm{K} /(\mathrm{Al}+\mathrm{Si})$ ratio in reactants varied from 0.048 to 0.961 ). Reaction temperature was $1100{ }^{\circ} \mathrm{C}$ and gas residence time was $1.2 \mathrm{~s}$. 


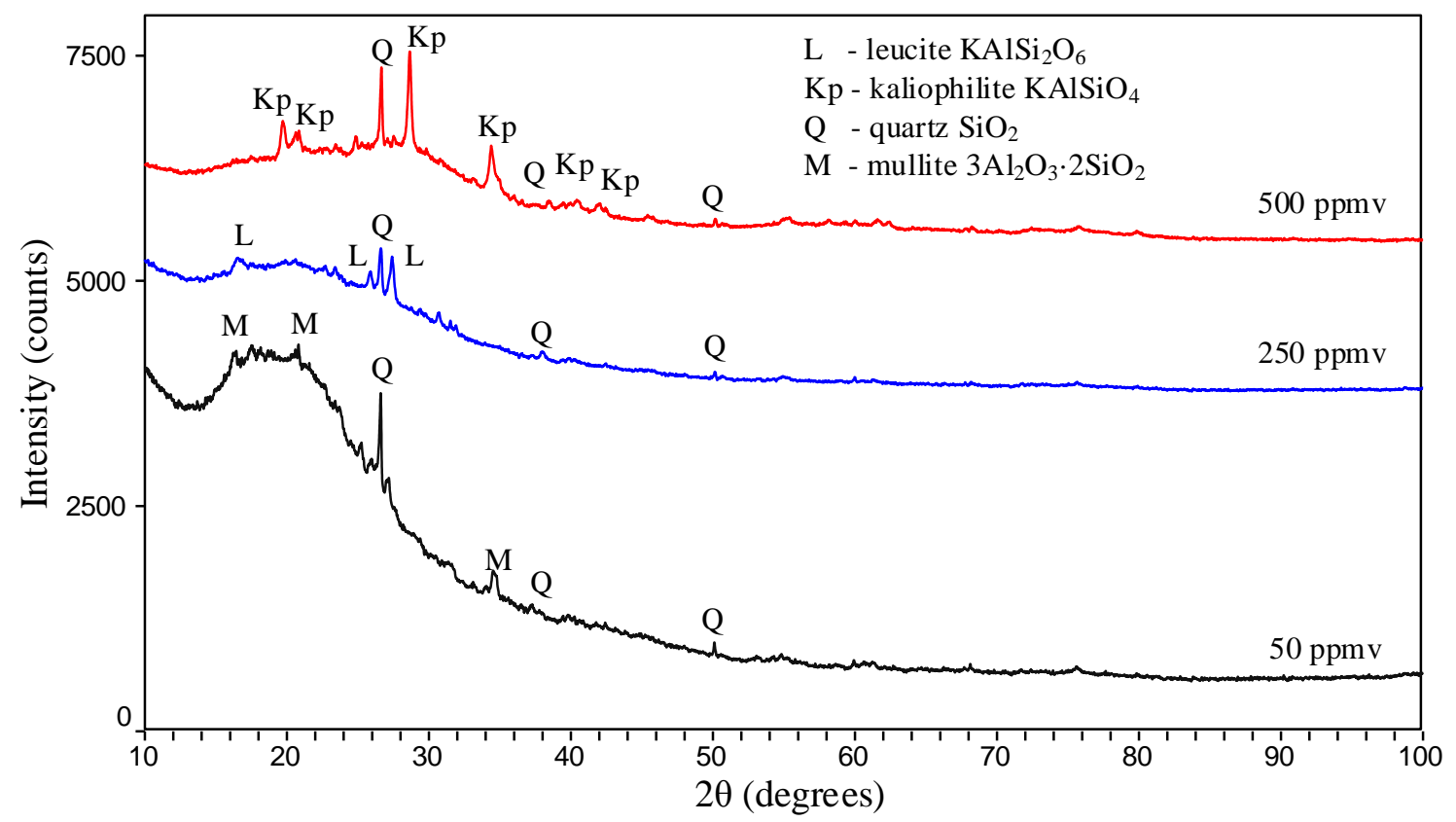

Figure 10. XRD spectra of water-washed KOH-reacted kaolin at 50, 250 and $500 \mathrm{ppmv} \mathrm{KOH}$. The reaction temperature was $1100{ }^{\circ} \mathrm{C}$, the molar ratio of $\mathrm{K} /(\mathrm{Al}+\mathrm{Si})$ was $0.048,0.240$ and 0.481 and the gas residence time was $1.2 \mathrm{~s}$. 


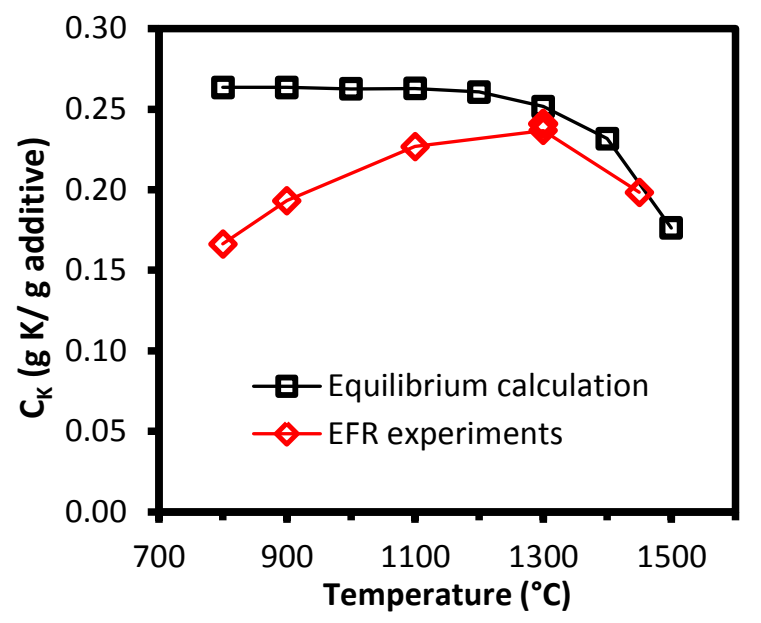

(A) $\mathrm{C}_{\mathrm{K}}$ at $500 \mathrm{ppmv} \mathrm{KOH}$

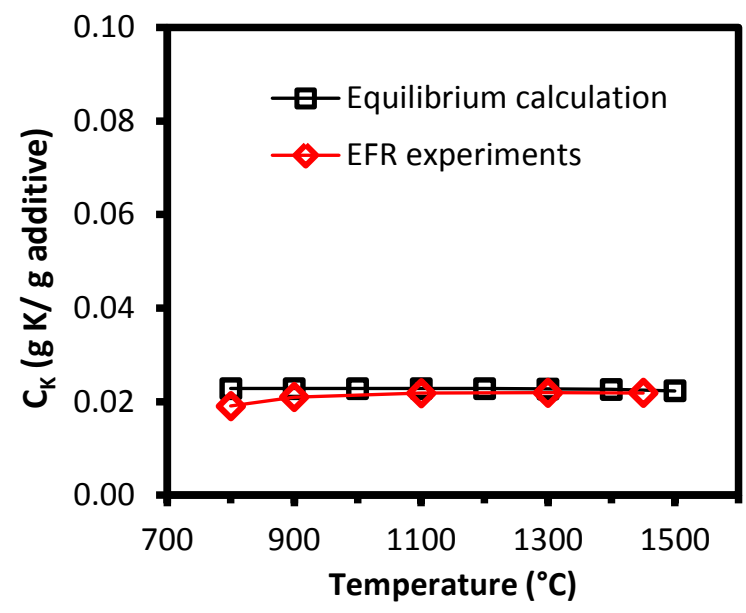

(C) $\mathrm{C}_{\mathrm{K}}$ at $50 \mathrm{ppmv} \mathrm{KOH}$

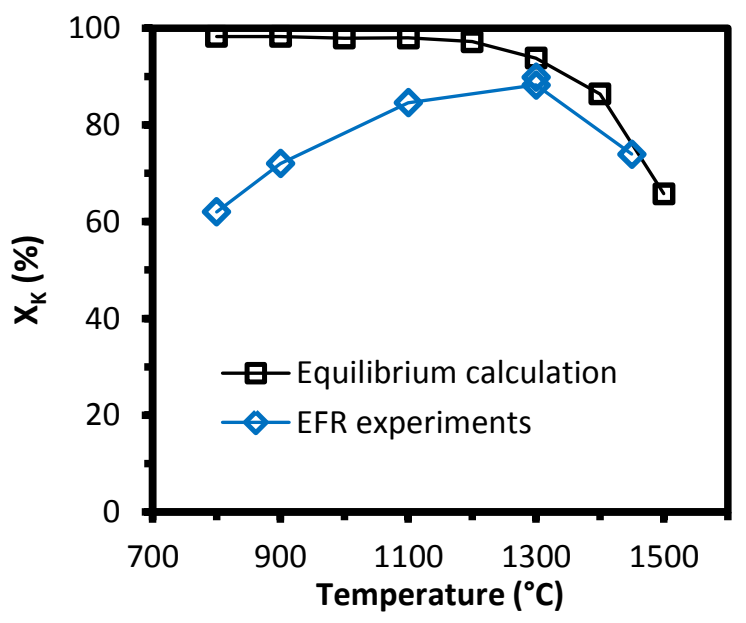

(B) $\mathrm{X}_{\mathrm{K}}$ at $500 \mathrm{ppmv} \mathrm{KOH}$

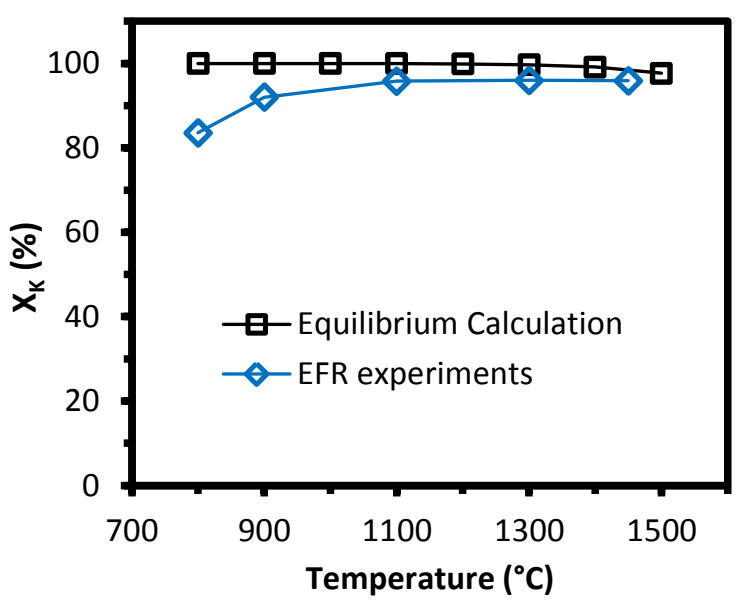

(D) $\mathrm{X}_{\mathrm{K}}$ at $50 \mathrm{ppmv} \mathrm{KOH}$

Figure 11. K-capture level $\left(\mathrm{C}_{\mathrm{K}}\right)$ and $\mathrm{K}$-conversion $\left(\mathrm{X}_{\mathrm{K}}\right)$ of $\mathrm{KOH}$ capture by normal kaolin $\left(\mathrm{D}_{50}=\right.$ $5.47 \mu \mathrm{m})$ at temperatures from 800 to $1450{ }^{\circ} \mathrm{C}$. $\mathrm{KOH}$-concentration was $500 \mathrm{ppmv}$, and molar $\mathrm{K} /(\mathrm{Al}+\mathrm{Si})$ ratio was 0.481 in $(\mathrm{A})$ and $(\mathrm{B}) ; \mathrm{KOH}-$ concentration was $50 \mathrm{ppmv}$, molar $\mathrm{K} /(\mathrm{Al}+\mathrm{Si})$ ratio was 0.048 in (C) and (D). Gas residence time was $1.2 \mathrm{~s}$ for all experiments, and equilibrium calculation results included for comparison. 


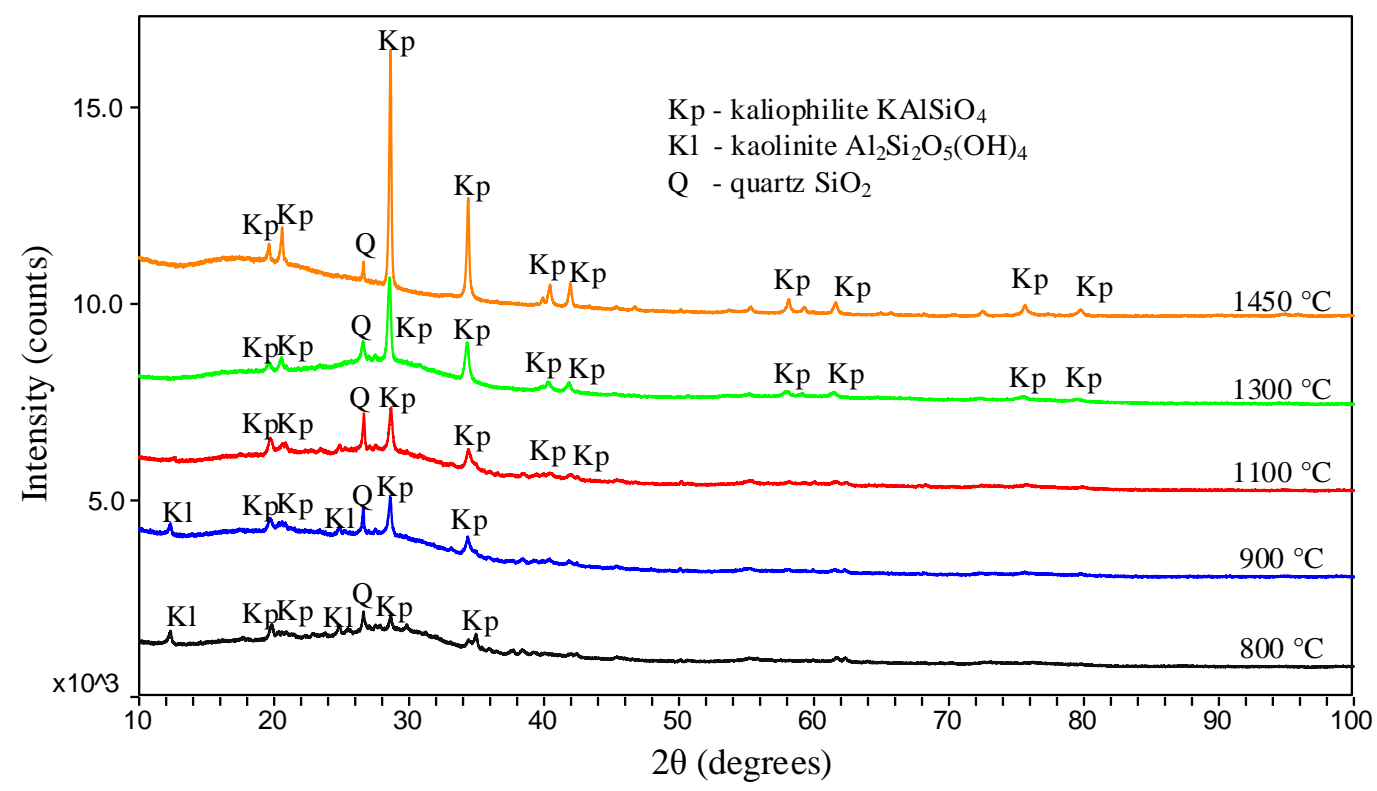

Figure 12. XRD spectra of water-washed solid samples from the experiments of KOH capture by normal kaolin $\left(\mathrm{D}_{50}=5.47 \mu \mathrm{m}\right)$ at different reaction temperatures, from $800{ }^{\circ} \mathrm{C}$ to $1450{ }^{\circ} \mathrm{C}$. $\mathrm{KOH}$ concentration was $500 \mathrm{ppmv},(\mathrm{K} /(\mathrm{Al}+\mathrm{Si})=0.481)$ and the gas residence time was $1.2 \mathrm{~s}$. 


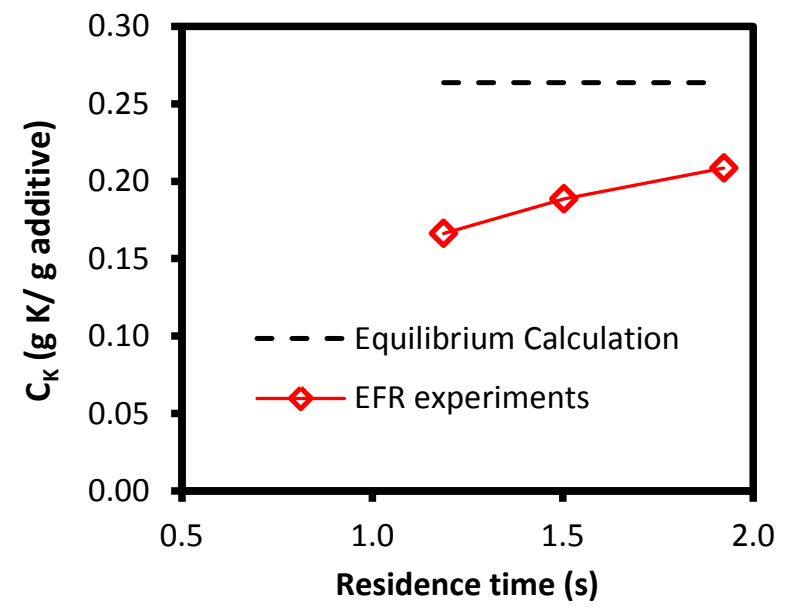

(A) $800{ }^{\circ} \mathrm{C}$

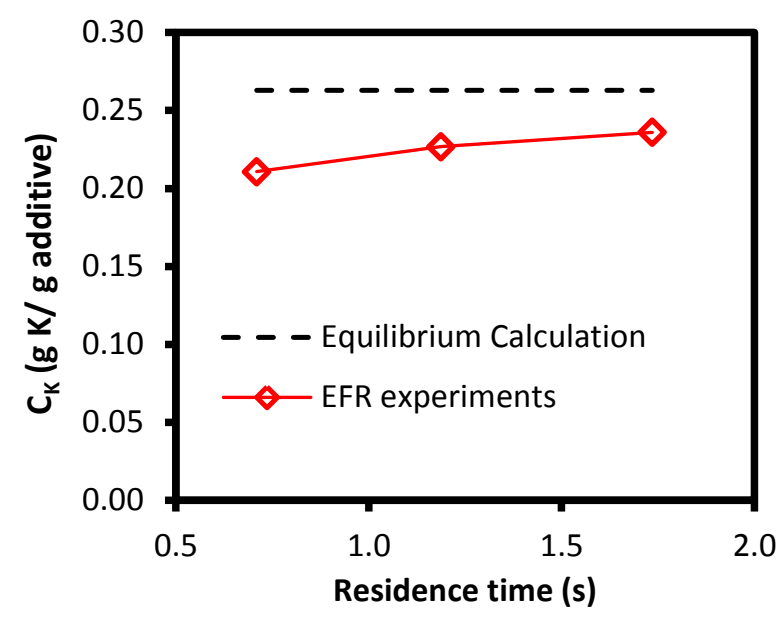

(B) $1100{ }^{\circ} \mathrm{C}$

Figure 13. K-capture level $\left(\mathrm{C}_{\mathrm{K}}\right)$ of $\mathrm{KOH}$ capture by the normal kaolin $\left(\mathrm{D}_{50}=5.47 \mu \mathrm{m}\right)$ at different gas residence times. Reaction temperature was $800{ }^{\circ} \mathrm{C}$ (A) and $1100{ }^{\circ} \mathrm{C}$ (B) respectively, and the $\mathrm{KOH}$-concentration was $500 \mathrm{ppmv}(\mathrm{K} /(\mathrm{Al}+\mathrm{Si})=0.481)$. Equilibrium calculation results are included for comparison. 


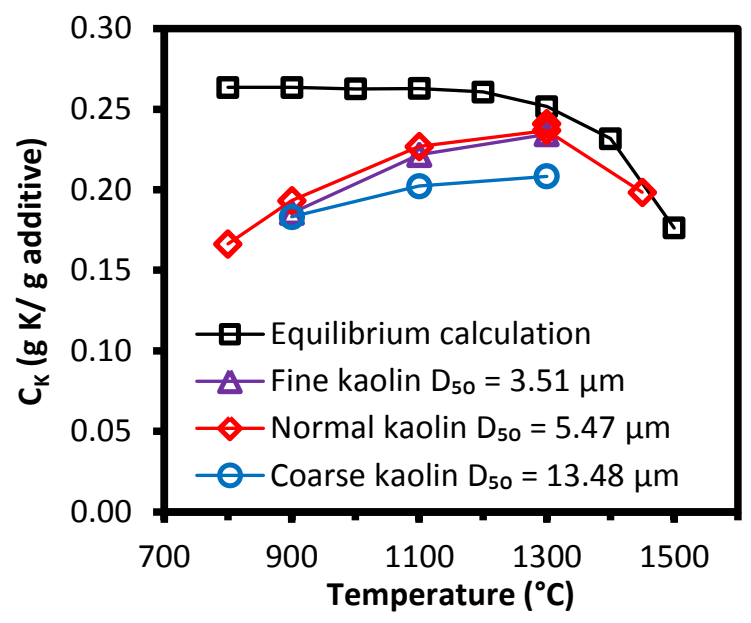

Figure 14. K-capture level $\left(\mathrm{C}_{\mathrm{K}}\right)$ of $\mathrm{KOH}$ capture by kaolin of different particle size: fine kaolin $\left(\mathrm{D}_{50}=3.51 \mu \mathrm{m}\right)$, normal kaolin $\left(\mathrm{D}_{50}=5.47 \mu \mathrm{m}\right)$ and coarse kaolin $\left(\mathrm{D}_{50}=13.48 \mu \mathrm{m}\right) . \mathrm{KOH}$ concentration was $500 \mathrm{ppmv}$ (molar ratio of $\mathrm{K} /(\mathrm{Al}+\mathrm{Si})$ in reactant was 0.481 ), and gas residence time was $1.2 \mathrm{~s}$. Equilibrium calculations are included for comparison.

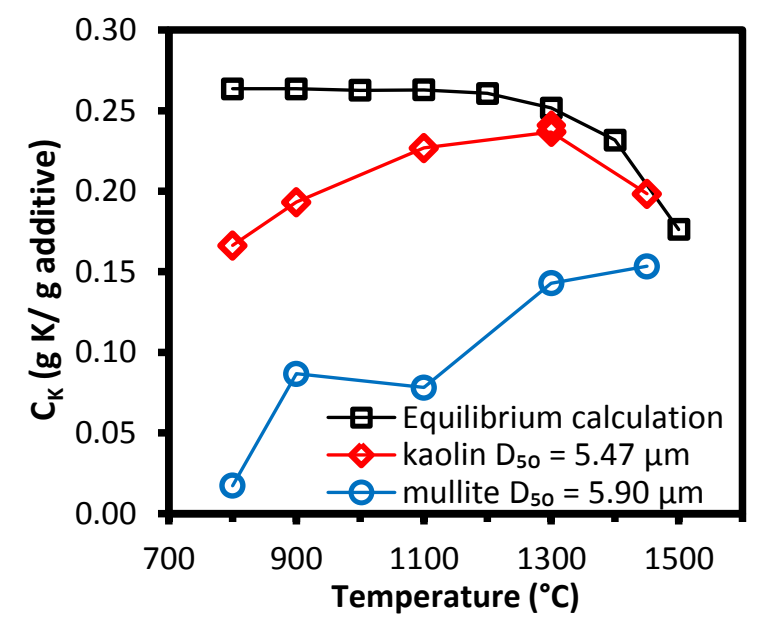

Figure 15. Comparison of K-capture level $\left(\mathrm{C}_{\mathrm{K}}\right)$ of $\mathrm{KOH}$ capture by kaolin and mullite. Reaction temperature changed from $800{ }^{\circ} \mathrm{C}$ to $1450{ }^{\circ} \mathrm{C}$. $\mathrm{KOH}$ concentration was $500 \mathrm{ppmv}(\mathrm{K} /(\mathrm{Al}+\mathrm{Si})=$ 
0.481), and gas residence time was $1.2 \mathrm{~s}$. Equilibrium calculation results are included for comparison. 


\section{TABLES}

Table 1. Characteristics of the solid additives.

\begin{tabular}{|c|c|c|c|c|}
\hline & Fine kaolin & Normal kaolin & Coarse kaolin & Mullite \\
\hline $\mathrm{O}$ (wt.\%, dry) & 56.9 & 56.9 & 55.88 & 51.30 \\
\hline S (wt.\%, dry) & 0.02 & 0.02 & 0.03 & 0.02 \\
\hline Si (wt.\%, dry) & 22.0 & 22.0 & 23.0 & 24.8 \\
\hline $\mathrm{Al}$ (wt.\%, dry) & 19.0 & 19.0 & 19.0 & 21.4 \\
\hline $\mathrm{Fe}$ (wt.\%, dry) & 0.47 & 0.47 & 0.46 & 0.53 \\
\hline $\mathrm{Ca}$ (wt.\%, dry) & 0.1 & 0.1 & 0.1 & 0.11 \\
\hline $\operatorname{Mg}$ (wt.\%, dry) & 0.14 & 0.14 & 0.12 & 0.16 \\
\hline $\mathrm{Na}$ (wt.\%, dry) & 0.1 & 0.1 & 0.1 & 0.1 \\
\hline K (wt.\%, dry) & 1.1 & 1.1 & 1.2 & 1.2 \\
\hline Ti (wt.\%, dry) & 0.02 & 0.02 & 0.01 & 0.02 \\
\hline P (wt.\%, dry) & 0.05 & 0.05 & 0.05 & 0.06 \\
\hline $\mathrm{Cl}$ (wt.\%, dry) & 0.1 & 0.1 & 0.05 & 0.11 \\
\hline $\mathrm{D}_{50}(\mu \mathrm{m})$ & 3.51 & 5.47 & 13.48 & 5.90 \\
\hline $\begin{array}{l}\text { BET surface } \\
\operatorname{area}\left(\mathrm{m}^{2} / \mathrm{g}\right)\end{array}$ & 13.02 & 12.70 & 11.83 & 5.30 \\
\hline
\end{tabular}


Table 2. Conditions of experiments in the Entrained Flow Reactor (EFR).

\begin{tabular}{|c|c|c|c|c|c|}
\hline Experimental series & Additives & Temp. $/{ }^{\circ} \mathrm{C}$ & $\begin{array}{c}\text { Gas } \\
\text { residence } \\
\text { time/s }\end{array}$ & $\begin{array}{c}\mathrm{K}- \\
\text { concentration } \\
/ \mathrm{ppmv} \\
\end{array}$ & $\mathbf{K} /(\mathbf{A l}+\mathbf{S i})$ \\
\hline \multirow{5}{*}{$\begin{array}{l}\text { (A) } \\
\text { KOH evaporation } \\
\text { experiments }\end{array}$} & \multirow{5}{*}{ No additive } & 800 & \multirow{5}{*}{1.2} & \multirow{5}{*}{500} & \multirow{5}{*}{ No Al, Si } \\
\hline & & 900 & & & \\
\hline & & 1100 & & & \\
\hline & & 1300 & & & \\
\hline & & 1450 & & & \\
\hline \multirow{5}{*}{$\begin{array}{l}\text { (B) } \\
\text { KOH-capture by } \\
\text { kaolin (impact of K- } \\
\text { concentration) }\end{array}$} & \multirow{5}{*}{$\begin{array}{c}\text { normal kaolin } \\
\left(\mathrm{D}_{50}=5.47 \mu \mathrm{m}\right)\end{array}$} & \multirow{5}{*}{1100} & \multirow{5}{*}{1.2} & 50 & 0.048 \\
\hline & & & & 250 & 0.240 \\
\hline & & & & 500 & 0.481 \\
\hline & & & & 750 & 0.721 \\
\hline & & & & 1000 & 0.961 \\
\hline \multirow{5}{*}{$\begin{array}{c}(\mathrm{C}) \\
\mathrm{KOH}-\mathrm{capture} \text { by } \\
\text { kaolin (impact of } \\
\text { temperature) }\end{array}$} & \multirow{5}{*}{$\begin{array}{c}\text { normal kaolin } \\
\left(\mathrm{D}_{50}=5.47 \mu \mathrm{m}\right)\end{array}$} & 800 & \multirow{5}{*}{1.2} & \multirow{5}{*}{50,500} & \multirow{5}{*}{$\begin{array}{l}0.048 \\
0.481\end{array}$} \\
\hline & & 900 & & & \\
\hline & & 1100 & & & \\
\hline & & $1300 *$ & & & \\
\hline & & 1450 & & & \\
\hline \multirow{4}{*}{$\begin{array}{l}\quad(\mathrm{D}) \\
\mathrm{KOH}-\mathrm{capture} \text { by } \\
\text { kaolin (impact of } \\
\text { residence time) }\end{array}$} & \multirow{4}{*}{$\begin{array}{l}\text { normal kaolin } \\
\left(\mathrm{D}_{50}=5.47 \mu \mathrm{m}\right)\end{array}$} & \multirow{4}{*}{800,1100} & 0.7 & \multirow{4}{*}{500} & \multirow{4}{*}{0.481} \\
\hline & & & 1.2 & & \\
\hline & & & 1.5 & & \\
\hline & & & 1.9 & & \\
\hline \multirow{3}{*}{$\begin{array}{c}\text { (E) } \\
\text { KOH-capture by } \\
\text { kaolin (impact of } \\
\text { kaolin particle size) }\end{array}$} & $\begin{array}{c}\text { fine kaolin } \\
\left(\mathrm{D}_{50}=3.51 \mu \mathrm{m}\right)\end{array}$ & $\begin{array}{c}900,1100 \\
1300 \\
\end{array}$ & \multirow{3}{*}{1.2} & \multirow{3}{*}{500} & \multirow{3}{*}{0.481} \\
\hline & $\begin{array}{c}\text { normal kaolin } \\
\left(\mathrm{D}_{50}=5.47 \mu \mathrm{m}\right)\end{array}$ & $\begin{array}{c}800,900, \\
1100,1300^{*}, \\
1450\end{array}$ & & & \\
\hline & $\begin{array}{c}\text { coarse kaolin } \\
\left(D_{50}=13.48 \mu \mathrm{m}\right)\end{array}$ & $\begin{array}{c}900,1100 \\
1300\end{array}$ & & & \\
\hline $\begin{array}{c}\mathrm{F}) \\
\mathrm{KOH} \text {-capture by } \\
\text { mullite }\end{array}$ & $\begin{array}{c}\text { Mullite } \\
\left(\mathrm{D}_{50}=5.90 \mu \mathrm{m}\right)\end{array}$ & $\begin{array}{c}800,900 \\
1100,1300 \\
1450\end{array}$ & 1.2 & 500 & 0.471 \\
\hline
\end{tabular}

Note: *Experiments were repeated. 
Table 3. Summary of the equilibrium calculation results of KOH capture by kaolin.

\begin{tabular}{|c|c|c|c|c|c|c|}
\hline Input conditions & Temp. $/{ }^{\circ} \mathrm{C}$ & K-species appearing & Al-con. & Si-con. & K-con. & $\begin{array}{c}\text { K-capture/(g } \\
\text { K/g kaolin) }\end{array}$ \\
\hline \multirow{5}{*}{$\begin{array}{c}50 \text { ppmv KOH, } \\
\mathrm{K} /(\mathrm{Al}+\mathrm{Si})=0.048\end{array}$} & 800 & $100 \% \mathrm{KAlSi}_{3} \mathrm{O}_{8}$ & $9 \%$ & $23 \%$ & $100 \%$ & 0.023 \\
\hline & 900 & $100 \% \mathrm{KAlSi}_{3} \mathrm{O}_{8}$ & $9 \%$ & $23 \%$ & $100 \%$ & 0.023 \\
\hline & 1100 & $100 \% \mathrm{KAlSi}_{3} \mathrm{O}_{8}$ & $9 \%$ & $23 \%$ & $100 \%$ & 0.023 \\
\hline & 1300 & $100 \% \mathrm{KAlSi}_{3} \mathrm{O}_{8}$ & $9 \%$ & $23 \%$ & $100 \%$ & 0.023 \\
\hline & 1450 & $99 \% \mathrm{KAlSi}_{3} \mathrm{O}_{8}+1 \% \mathrm{KOH}$ & $9 \%$ & $23 \%$ & $99 \%$ & 0.022 \\
\hline \multirow{5}{*}{$\begin{array}{c}250 \mathrm{ppmv} \mathrm{KOH} \\
\mathrm{K} /(\mathrm{Al}+\mathrm{Si})=0.240\end{array}$} & 800 & $25 \% \mathrm{KAlSi}_{3} \mathrm{O}_{8}+75 \% \mathrm{KAlSi}_{2} \mathrm{O}_{6}$ & $49 \%$ & $98 \%$ & $100 \%$ & 0.129 \\
\hline & 900 & $25 \% \mathrm{KAlSi}_{3} \mathrm{O}_{8}+75 \% \mathrm{KAlSi}_{2} \mathrm{O}_{6}$ & $49 \%$ & $98 \%$ & $100 \%$ & 0.129 \\
\hline & 1100 & $24 \% \mathrm{KAlSi}_{3} \mathrm{O}_{8}+76 \% \mathrm{KAlSi}_{2} \mathrm{O}_{6}$ & $49 \%$ & $97 \%$ & $100 \%$ & 0.129 \\
\hline & 1300 & $20 \% \mathrm{KAlSi}_{3} \mathrm{O}_{8}+80 \% \mathrm{KAlSi}_{2} \mathrm{O}_{6}$ & $49 \%$ & $96 \%$ & $100 \%$ & 0.128 \\
\hline & 1450 & $22 \% \mathrm{KAlSi}_{3} \mathrm{O}_{8}+77 \% \mathrm{KAlSi}_{2} \mathrm{O}_{6}$ & $49 \%$ & $96 \%$ & $99 \%$ & 0.128 \\
\hline \multirow{5}{*}{$\begin{array}{c}500 \mathrm{ppmv} \mathrm{KOH}, \\
\mathrm{K} /(\mathrm{Al}+\mathrm{Si})=0.481\end{array}$} & 800 & $92 \% \mathrm{KAlSiO}_{4}+6 \% \mathrm{KAlSi}_{2} \mathrm{O}_{6}$ & $100 \%$ & $98 \%$ & $98 \%$ & 0.264 \\
\hline & 900 & $91 \% \mathrm{KAlSiO}_{4}+7 \% \mathrm{KAlSi}_{2} \mathrm{O}_{6}+1 \% \mathrm{KOH}$ & $100 \%$ & $99 \%$ & $98 \%$ & 0.264 \\
\hline & 1100 & $91 \% \mathrm{KAlSiO}_{4}+7 \% \mathrm{KAlSi}_{2} \mathrm{O}_{6}+2 \% \mathrm{KOH}$ & $100 \%$ & $99 \%$ & $98 \%$ & 0.263 \\
\hline & 1300 & $82 \% \mathrm{KAlSiO}_{4}+12 \% \mathrm{KAlSi}_{2} \mathrm{O}_{6}+6 \% \mathrm{KOH}$ & $95 \%$ & $100 \%$ & $94 \%$ & 0.252 \\
\hline & 1450 & $50 \% \mathrm{KAlSiO}_{4}+28 \% \mathrm{KAlSi}_{2} \mathrm{O}_{6}+21 \% \mathrm{KOH}$ & $79 \%$ & $100 \%$ & $78 \%$ & 0.209 \\
\hline \multirow{5}{*}{$\begin{array}{c}750 \mathrm{ppmv} \mathrm{KOH}, \\
\mathrm{K} /(\mathrm{Al}+\mathrm{Si})=0.721\end{array}$} & 800 & $57 \% \mathrm{KAlSiO}_{4}+8 \% \mathrm{KAlO}_{2}+31 \% \mathrm{~K}_{2} \mathrm{SiO}_{3}+3 \% \mathrm{KOH}$ & $88 \%$ & $78 \%$ & $57 \%$ & 0.231 \\
\hline & 900 & $63 \% \mathrm{KAlSiO}_{4}+1 \% \mathrm{KAlO}_{2}+18 \% \mathrm{~K}_{2} \mathrm{SiO}_{3}+16 \% \mathrm{KOH}$ & $98 \%$ & $87 \%$ & $63 \%$ & 0.258 \\
\hline & 1100 & $65 \% \mathrm{KAlSiO}_{4}+8 \% \mathrm{~K}_{2} \mathrm{Si}_{2} \mathrm{O}_{5}+27 \% \mathrm{KOH}$ & $100 \%$ & $89 \%$ & $65 \%$ & 0.263 \\
\hline & 1300 & $57 \% \mathrm{KAlSiO}_{4}+8 \% \mathrm{KAlSi}_{2} \mathrm{O}_{6}+35 \% \mathrm{KOH}$ & $100 \%$ & $100 \%$ & $65 \%$ & 0.263 \\
\hline & 1450 & $57 \% \mathrm{KAlSiO}_{4}+8 \% \mathrm{KAlSi}_{2} \mathrm{O}_{6}+35 \% \mathrm{KOH}$ & $100 \%$ & $100 \%$ & $65 \%$ & 0.263 \\
\hline \multirow{5}{*}{$\begin{array}{l}1000 \text { ppmv KOH, } \\
\mathrm{K} /(\mathrm{Al}+\mathrm{Si})=0.961\end{array}$} & 800 & $29 \% \mathrm{KAlSiO}_{4}+19 \% \mathrm{KAlO}_{2}+49 \% \mathrm{~K}_{2} \mathrm{SiO}_{3}+3 \% \mathrm{KOH}$ & $61 \%$ & $55 \%$ & $29 \%$ & 0.161 \\
\hline & 900 & $35 \% \mathrm{KAlSiO}_{4}+13 \% \mathrm{KAlO}_{2}+38 \% \mathrm{~K}_{2} \mathrm{SiO}_{3}+14 \% \mathrm{KOH}$ & $73 \%$ & $65 \%$ & $35 \%$ & 0.191 \\
\hline & 1100 & $48 \% \mathrm{KAlSiO}_{4}+11 \% \mathrm{~K}_{2} \mathrm{SiO}_{3}+41 \% \mathrm{KOH}$ & $100 \%$ & $89 \%$ & $48 \%$ & 0.264 \\
\hline & 1300 & $43 \% \mathrm{KAlSiO}_{4}+6 \% \mathrm{KAlSi}_{2} \mathrm{O}_{6}+52 \% \mathrm{KOH}$ & $100 \%$ & $100 \%$ & $48 \%$ & 0.264 \\
\hline & 1450 & $43 \% \mathrm{KAlSiO}_{4}+6 \% \mathrm{KAlSi}_{2} \mathrm{O}_{6}+51 \% \mathrm{KOH}+1 \% \mathrm{~K}$ & $100 \%$ & $100 \%$ & $48 \%$ & 0.264 \\
\hline
\end{tabular}


